\section{Nutrient Management with Cover Crops and Compost Affects Development and Yield in Organically Managed Sweetpotato Systems}

\author{
Danielle D. Treadwell ${ }^{1,3,4}$ and Nancy G. Creamer ${ }^{2}$ \\ Department of Horticultural Science, Campus Box 7609, North Carolina \\ State University, Raleigh, NC 27529-7609
}

\section{Greg D. Hoyt ${ }^{2}$}

Department of Soil Science, North Carolina State University, 455 Research Dr., Fletcher, NC 28732

\author{
Jonathan R. Schultheis ${ }^{2}$ \\ Department of Horticultural Science, Campus Box 7609, North Carolina \\ State University, Raleigh, NC 27529-7609
}

Additional index words. hairy vetch (Vicia villosa), rye (Secale cereale) 'Wrens Abruzzi', Ipomoea batatas 'Beauregard', organic production, soil N, tissue N, biomass, conventional

\begin{abstract}
A 3-year field experiment was initiated in 2001 to evaluate different organic sweetpotato production systems that varied in cover crop management and tillage. Three organic systems: 1) compost and no cover crop with tillage (Org-NCC); 2) compost and a cover crop mixture of hairy vetch and rye incorporated before transplanting (Org-CCI); and 3) compost and the same cover crop mixture with reduced tillage (Org-RT) were compared with a conventionally managed system (Conv) with tillage and chemical controls. Yield of No. 1 sweetpotato roots and total yield were similar among management systems each year, except for a reduction in yield in Org-RT in 2002. The percentage of No. 1 grade roots was at least $17 \%$ and $23 \%$ higher in Org-CCI and OrgNCC than Org-RT in 2001 and 2002, respectively, and similar to Conv in 2001 and 2004. Organic and conventional $\mathbf{N}$ sources contributed to soil inorganic $\mathbf{N}$ reserves differently the 2 years this component was measured. In 2002, soil inorganic $\mathrm{N}$ reserves at 30 DAT were in the order: Org-CCI $\left(90 \mathrm{~kg} \cdot \mathrm{ha}^{-1}\right)>\operatorname{Org}-\mathrm{NCC}\left(67 \mathrm{~kg} \cdot \mathrm{ha}^{-1}\right)>\operatorname{Org}-\mathrm{RT}\left(45 \mathrm{~kg} \cdot \mathrm{ha}^{-1}\right)$, and Conv $\left(55 \mathrm{~kg} \cdot \mathrm{ha}^{-1}\right)$. No differences in soil inorganic $\mathrm{N}$ reserves were observed among systems in 2004. Sweetpotato $N$, $P$, and $K$ tissue concentrations were different among systems only in 2004. That year, at 60 days after transplanting, tissue $\mathrm{N}, \mathrm{P}$, and $\mathrm{K}$ were greatest in Org-CCI. In 2001 and $2004, \mathrm{~N}(4.09 \%$ to $4.56 \%)$ and $\mathrm{K}(3.79 \%$ to $4.34 \%)$ were higher than sufficiency ranges for $N(3.2 \%$ to $4.0 \%)$ and $K(2.5 \%$ to $3.5 \%)$ defined by North Carolina Department of Agriculture and Consumer Services recommendations for all treatments. No tissue macronutrient or micronutrient concentrations were limiting during this experiment. Reduced rainfall during the 2002 sweetpotato growing season may have contributed to the low microbially mediated plant-available $\mathbf{N}$ from the organic fertilizer sources. Despite differences in the nutrient content of organic and conventional fertility amendments, organically managed systems receiving compost with or without incorporated hairy vetch and rye produced yields equal to the conventionally managed system.
\end{abstract}

\footnotetext{
Received for publication 11 Feb. 2008. Accepted for publication 24 Apr. 2008.

This research was funded in part by the Sustainable Agriculture Research and Education Program (GS000-006) and NC Agricultural Foundation. We thank Cavell Brownie for statistical advice and Edward Pitzer, Kenneth Fager, and Toby Grimes for technical assistance.

${ }^{1}$ Graduate Research Assistant.

${ }^{2}$ Professor.

${ }^{3}$ Current address: Department of Horticultural Sciences, University of Florida, P.O. Box 110690 , Gainesville, FL 32611-0690.

${ }^{4}$ To whom reprint requests should be addressed; e-mail ddtreadw@ufl.edu
}

In 2004, North Carolina supplied $46 \%$ of the nations' sweetpotatoes and generated $\$ 79$ million for the state's farmers [North Carolina Department of Agriculture and Consumer Services (NCDA \& CS), 2005]. Although there were over 16,000 ha of sweetpotatoes in production for the 2004 growing season, less than $4 \%$ of those hectares were managed according to national organic standards (K. Hardison, personal communication, 2005). The U.S. Department of Agriculture ERS reports that organic foods are sold in $73 \%$ of all traditional food markets (Dimitri and Greene, 2003), and in 2005, total organic food sales were estimated at $\$ 13.8$ billion U.S. [Organic Trade Association (OTA), 2006]. Approximately 39\% of those sales were fruits and vegetables, and market penetration of organic food is estimated at $2.48 \%$ of total U.S. food sales (OTA, 2006). Despite the demand for organic produce, few research-based production recommendations exist for organic fresh market vegetables.

The cultivar Beauregard is the predominant variety grown in the United States (Schultheis et al., 1999). It produces more No. 1 grade sweetpotatoes, has a shorter season, and is more broadly adapted in the southeastern United States than other commercial cultivars such as 'Jewel' or 'Centennial' (Rolston et al., 1987). Optimum N requirements for 'Beauregard' range from 28 to $56 \mathrm{~kg} \cdot \mathrm{ha}^{-1} \mathrm{~N}$ applied 2 to 4 weeks after planting (Phillips et al., 2005; Schultheis and Jester, 2002). Growers in North Carolina typically apply $56 \mathrm{~kg} \mathrm{~N}, 112$ to $168 \mathrm{~kg} \mathrm{~K}$, $112 \mathrm{~kg} \mathrm{P}$ as well as $0.6 \mathrm{~kg} \cdot \mathrm{ha}^{-1}$ boron for control of a nutrient disorder called blister. The number of days until storage root initiation and canopy development varies among sweetpotato cultivars (La Bonte et al., 1999; Schultheis et al., 1999). In 'Beauregard', root initiation is visually detectable $\approx 28 \mathrm{~d}$ after transplanting (DAT) (Seem et al., 2003), whereas leaf canopy development peaks $\approx 60$ DAT (Jett and Talbot, 1998) followed by harvest between 90 and 110 DAT.

Commercial sweetpotato growers typically use multiple tillage events, including subsoiling, disking, hilling, and cultivation. In North Carolina, common rotational crops include tobacco (Nicotiana tabacum L.), cotton (Gossypium hirsutum L.), soybean [Glycine $\max$ (L.) Merr.], and mixed vegetables (Toth et al., 1997). Insect and nematode control is largely preventive and may include preplant soil fumigation and preplant and postemergent insecticides. The extensive tillage and high number of vehicle passes required to manage sweetpotato as well as its associated rotational crops can lead to loss of organic matter, decline of soil structure, and soil loss resulting from wind and water erosion after soil disturbance.

Organic soil amendments such as compost and cover crops are integral components in organic management systems. Compost is applied to promote soil biological activity (Raviv, 2005), suppress disease (Stone et al., 2003), increase soil organic C (Jackson et al., 2004) and supply nutrients (Gagnon et al., 1998). The compost application rate is often determined based on its estimated plantavailable N (PAN). However, the amount of PAN and the timing of organic $\mathrm{N}$ transformations are difficult to predict because they are dependent on properties inherent to the compost, including $\mathrm{C}: \mathrm{N}$ ratio and nitrogen fractions (Cabrera et al., 2005), and environmental conditions, including soil temperature (Kätterer et al., 1998) and soil moisture (Linn and Doran, 1984; Senesvirante et al., 1998). Synchronizing PAN with plant demand is one of the most difficult aspects of organic crop production. Currently, there are no reliable methods to predict PAN 
from organic fertility sources (Cabrera et al., 2005; Gaskell and Smith, 2007).

Winter annual cover crops such as hairy vetch and rye reduce nitrate leaching and soil carbon losses (Drinkwater et al., 1998; Jackson et al., 2004; Ranells and Wagger, 1997), improve nutrient use efficiency (Staver and Brinsfield, 1998), increase soil microbial biomass (Jackson et al., 2004; Mendes et al., 1999), increase water retention (Liebl et al., 1992), and decrease soil bulk density (Jackson et al., 2004). Increasing soil organic matter with cover crop incorporation can occur with repeated applications, although in most soils, the increase in measurable organic matter is slight (Stinner et al., 1983). In areas of the North Carolina coastal plain where percent soil organic matter is very low, an increase in soil organic matter is possible with repeated incorporations of cover crop biomass over time. However, in the southeastern United States, the objective of increasing organic matter is secondary to replacing fertilizer $\mathrm{N}$ with legume $\mathrm{N}$ (Ranells and Wagger, 1997).

Hairy vetch and rye are cover crop species that establish easily, overwinter successfully, produce sufficient biomass, and are easily killed in the spring by mechanical methods (Creamer et al., 1997). Crop N recovery from winter annual cover crop mixtures depends on inherent soil $\mathrm{N}$, residue quality and quantity of component cover species, tillage, climate, and soil characteristics. For optimum $\mathrm{N}$ availability to the subsequent crop, a C:N ratio of 20:1 to $30: 1$ at the time of kill is desired (Creamer et al., 1997; Ranells and Wagger, 1997). In the coastal plain of North Carolina, rye and hairy vetch are seeded in an $\approx 2: 1$ ratio. Actual C:N ratios of hairy vetch and rye mixtures for this seeding ratio are typically less than 30:1 (Ranells and Wagger, 1997); thus, crops after incorporation of a similar winter annual hairy vetch and rye mixture would most likely experience minimal N stress associated with $\mathrm{N}$ immobilization. When cover crop incorporation takes place before planting, subsequent crops benefit by the slow release of nutrients (Wilson and Hargrove, 1986). If allowed to remain on the surface, mixtures have slower surface decomposition than legumes alone (Creamer et al., 1997) and can provide significant suppression of weeds for the next crop (Creamer et al., 1996).

Recent reports on reduced tillage vegetable systems indicate the benefits of surface mulch are best realized when the duration of the crop season is long (Hoyt, 1999). 'Beauregard' sweetpotato has a 90 - to 110 -d growing season and a moderately low fertility requirement and therefore is a suitable candidate for cover crop inclusion. In a Louisiana study of cover crop use in a conventional sweetpotato 'Beauregard' system, Jett and Talbot (1998) found that when incorporated, rye and ryegrass reduced soil erosion and increased yields of sweetpotato. In a subsequent study, sweetpotatoes growing in undisturbed rye residue had higher leaf area, vine weight, root set, and yield relative to conventional tilled sweetpotatoes (Jett, 1999). The researchers hypothesized that the cover crop residue favorably modified the soil environment by eliminating early restriction to root set often caused by high soil temperatures (Jett, 1999).

Several studies have been performed in the southeast to determine the influence of nutrient source and/or rate on sweetpotato root yield under conventional management (Hammett et al., 1984; Mascianica et al., 1985; Nicholaides et al., 1985; Phillips et al., 2005; Purcell et al., 1982), but no such data have been collected for organic systems. To assess the adequacy of nutrient supply and to examine the influence of cover crop management on sweetpotato nutrient uptake and productivity, a 3-year field experiment was designed to test three organically managed systems with and without cover crops and tillage compared with a conventionally managed system with tillage and chemical pest controls.

\section{Materials and Methods}

Experiments were conducted in 2001, 2002, and 2004 at the Center for Environmental Farming Systems, Goldsboro, NC. In all 3 years, the soil was a Wickham loamy sand (fine-loamy, mixed, semiactive, thermic Typic Hapludults). This series is a representative soil of the central coastal plain in North Carolina and is typical of sweetpotato production areas in North Carolina. This soil is sedimentary in origin, acidic, low in nutrient holding capacity, and subject to occasional flooding. Preceding crops on experimental sites for 2001, 2002, and 2004, respectively, were as follows: perennial ryegrass (Lolium perenne L.), conventionally managed field corn (Zea mays L.), and sorghum sudangrass [Sorghum bicolor (L.) Moench $\times S$. sudanense (Piper) Staph]. Organic production practices followed guidelines published by an independent certifying agency (Carolina Farm Stewardship Association, 1997) in 2001 and the U.S. National Organic Standards established by the National Organic Program (U.S. Department of Agriculture and the Agricultural Marketing Service, 2002) for the 2002 and 2004 growing seasons. Each year, the experiment was located on land previously managed conventionally; therefore, the effects of these treatments should be considered to represent transitional organic systems rather than a fully functioning ecological and certified organic system.

Treatments were arranged in a randomized complete block experimental design and replicated six times. The three organically managed systems included 1) compost and no cover crop with tillage (Org-NCC); 2) compost and cover crop incorporated before transplanting (Org-CCI); and 3) compost and cover crop with reduced tillage (Org-RT). These systems were compared with a conventional system that included tillage, synthetic fertilizer, and chemical controls (Conv) to determine the effects of cover crop management on soil nutrient reserves, sweet- potato nutrient acquisition, and sweetpotato productivity. Large plot sizes were used to accommodate full-sized farm equipment to mimic conditions typical of sweetpotato farms in North Carolina. Plots were $24.4 \mathrm{~m}$ long and composed of 12 rows on $1-m$ centers in 2001 and 2002 and $0.96-\mathrm{m}$ centers in 2004. A minimum of 9.1-m $(2001,2002)$ and $6.1-\mathrm{m}$ (2004) buffer separated replications. The area surrounding each replication was planted in ryegrass in early spring and maintained by mowing throughout the season. The total experimental area was $\approx 1$ ha, and the experimental location was moved each year. Because site conditions varied among years in field history, soil condition, pest populations, and climate, variation of some methods was necessary to optimize the production of each system. A summary of cultural practices is presented in Table 1 .

Based on soil test results from NCDA \& CS Agronomic Division, boron was applied to all plots before planting at a rate of $0.6 \mathrm{~kg} \cdot \mathrm{ha}^{-1}$ [Solubor $\left(\mathrm{Na}_{2} \cdot \mathrm{B}_{8} \cdot \mathrm{O}_{13} \cdot 4 \mathrm{H}_{2} \mathrm{O}\right)$; U.S. Borax, Valencia, CA]. In the conventionally managed treatment, ammonium nitrate $\left(\mathrm{NH}_{4} \mathrm{NO}_{3}\right)$ at $56 \mathrm{~kg} \cdot \mathrm{ha}^{-1}$ was surfacebanded and incorporated in the row 28 DAT each year. All three organically managed treatments received compost composed primarily of turkey litter at a rate of $20 \mathrm{Mg} \cdot \mathrm{ha}^{-1}$ before transplanting in Spring 2001 and in the fall before sweetpotato production in 2002 and 2004. Compost was approved for use in organic production by the Organic Materials Review Institute. Organic treatments receiving cover crops were seeded with a mixture of $45 \mathrm{~kg} \cdot \mathrm{ha}^{-1}$ hairy vetch (Vicia villosa Roth) inoculated with Rhizobium spp. and 67 $\mathrm{kg} \cdot \mathrm{ha}^{-1}$ rye (Secale cereale L.) 'Wrens Abruzzi'. These cover crop seeding rates are typical for plant establishment in the coastal plain. As a result of the complexity of interactions that moderate $\mathrm{N}$ mineralization, $\mathrm{N}$ release from organic sources can be difficult to accurately predict. Thus, $\mathrm{N}$ contributions from compost and cover crops were estimated based on total $\mathrm{N}$ concentration and availability coefficients.

In 2001, compost was broadcast and incorporated with a tandem disk harrow in May in organic treatments amendable to tillage (Org-NCC and Org-CCI) after cover crop termination in Org-CCI and surfacebroadcast onto untilled, ended cover crop biomass in Org-RT plots before transplanting. For 2002 and 2004 crops, compost was incorporated in November before planting cover crops in all organic treatments. Before application and according to NCDA \& CS Agronomic Division laboratory analysis, total compost $\mathrm{N}$ was $318 \mathrm{~kg} \cdot \mathrm{ha}^{-1}$ in 2001 , $248 \mathrm{~kg} \cdot \mathrm{ha}^{-1}$ in 2002, and $286 \mathrm{~kg} \cdot \mathrm{ha}^{-1}$ in 2004.

Commercially grown 'Beauregard' B9414 G2 (G2 represents plants that are the second generation produced outside a virusfree greenhouse environment. B94-14 represents a Beauregard cultivar mericlone.) slips were planted using $0.27-\mathrm{m}$ in-row spacing on 2 July 2001, 13 June 2002, and 29 June 2004. Conventional slips were produced according 
Table 1. Dates of cultural practices relevant to nutrient management in management systems in 2001, 2002 , and 2004

\begin{tabular}{|c|c|c|c|}
\hline \multirow[b]{2}{*}{ Treatment } & \multicolumn{3}{|c|}{ Date of cultural practice } \\
\hline & 2001 & 2002 & 2004 \\
\hline \multicolumn{4}{|l|}{$\mathrm{Org}^{-\mathrm{NCC}^{\mathrm{z}}}$} \\
\hline Apply compost & 19 June & $6 \mathrm{Nov}$ & $12 \mathrm{Nov}$ \\
\hline Tandem disk harrow & 22 June & $8 \mathrm{Nov}$ & $13 \mathrm{Nov}$ \\
\hline Tandem disk harrow & - & 3 May & 3 June \\
\hline Disk-ridge hills & 27 June & 10 June & 22 June \\
\hline Tandem disk harrow & - & 12 June & - \\
\hline \multicolumn{4}{|l|}{ Org-CCI } \\
\hline Apply compost & 19 June & $6 \mathrm{Nov}$ & $12 \mathrm{Nov}$ \\
\hline Tandem disk harrow & 22 June & $8 \mathrm{Nov}$ & $13 \mathrm{Nov}$ \\
\hline Plant cover crop & $30 \mathrm{Nov}$ & $8 \mathrm{Nov}$ & $13 \mathrm{Nov}$ \\
\hline Kill cover crop & 9 May & 1 May & 11 May \\
\hline Incorporate cover & 23 May & 3 May & 11 May \\
\hline Tandem disk harrow & - & - & 3 June \\
\hline Disk-ridge hills & 27 June & 10 June & 22 June \\
\hline Tandem disk harrow & - & 12 June & - \\
\hline \multicolumn{4}{|l|}{ Org-RT } \\
\hline Apply compost & 19 June & $6 \mathrm{Nov}$ & $12 \mathrm{Nov}$ \\
\hline Tandem disk harrow & - & $8 \mathrm{Nov}$ & $13 \mathrm{Nov}$ \\
\hline Disk-ridge hills & $30 \mathrm{Nov}$ & $8 \mathrm{Nov}$ & $13 \mathrm{Nov}$ \\
\hline Plant cover crop & $30 \mathrm{Nov}$ & $8 \mathrm{Nov}$ & $13 \mathrm{Nov}$ \\
\hline Kill cover crop & 2 July & 1 May & 20 May \\
\hline \multicolumn{4}{|l|}{ Conventional } \\
\hline Tandem disk harrow & - & 3 May & - \\
\hline Tandem disk harrow & 27 June & 12 June & 3 June \\
\hline Apply $\mathrm{NH}_{4} \mathrm{NO}_{3}$ & 30 July & 10 July & 27 July \\
\hline Disk-ridge hills & 27 June & 10 June & 22 June \\
\hline \multicolumn{4}{|l|}{ All treatments } \\
\hline Apply boron & 24 May & 4 May & 20 May \\
\hline Plant & 2 July & 13 June & 29 June \\
\hline Harvest & $15 \mathrm{Oct}$ & $26 \mathrm{Sept}$ & $1 \mathrm{Oct}$ \\
\hline
\end{tabular}

$\overline{{ }^{\mathrm{z}} \mathrm{Org}-\mathrm{NCC}}=$ organically managed, no cover crop; Org-CCI = organically managed, cover crop incorporated; Org-RT $=$ organically managed, reduced tillage, Conventional $=$ conventionally managed control.

to standard production practices for our area (Wilson et al., 1989) and were obtained from a local farm. Conventionally produced slips were used for all treatments in 2001 because organically produced slips were not available. However, in 2002 and 2004, organic slips from a local farm after organic production practices were used for the organic treatments. Compost approved for organic production was broadcast at $15,680 \mathrm{~kg} \cdot \mathrm{ha}^{-1}$ and incorporated on 91-cm beds. Organically produced seed sweetpotatoes were placed in beds in March, covered with black plastic mulch, and provided drip irrigation. After plant emergence, the black plastic was removed, and shoots were mowed two to three times to ensure height uniformity before hand cutting. Slips were cut by hand in late May. For all treatments, slips were unrooted $25-\mathrm{cm}$ tip cuttings and were planted to a depth of four nodes. Within 2 weeks of planting, sweetpotato slips were replanted by hand $(5 \%$ to $10 \%)$ as necessary to ensure an equal stand among treatments. After sweetpotato transplanting, weeds were controlled by a rolling cultivator until vine growth between the rows prohibited equipment traffic, at which time remaining weeds were removed by mowing above the sweetpotato canopy or removed by hand. A detailed discussion of weed management and impact in these systems can be found at Treadwell et al. (2007). Before harvest, sweetpotato foliage was mowed with a rotary mower (Bush Hog, L.L.C., Selma, AL), and sweet- potato roots were brought to the soil surface with a mechanical two row digger (KMC, Tifton, GA).

\section{Treatment management}

Organic, no cover crop (Org-NCC). Plots were tilled with a tandem disc harrow to eliminate weeds in late November (Table 1). In May, overwintering weeds were incorporated with a tandem disc harrow followed by one additional discing $\approx 2$ weeks later. Hills were formed with a ripper-bedder several days before sweetpotato planting. Slips were planted with a two row transplanter (RJ Equipment, Blenheim, Ontario, Canada).

Organic, cover crop incorporated (OrgCCI). A cover crop mixture of $45 \mathrm{~kg} \cdot \mathrm{ha}^{-1}$ hairy vetch and $67 \mathrm{~kg} \cdot \mathrm{ha}^{-1}$ rye 'Wrens Abruzzi' was seeded in November all 3 years with a grain drill on a disked flat soil surface (Table 1). Cover crops were flail mowed when hairy vetch was in midbloom (Creamer et al., 1995) and rye was in anthesis on 23 May 2001, 3 May 2002, and 3 June 2004. In 2001 , as a result of an abundance of cover crop biomass and dry, compacted soil, it was necessary to use a moldboard plow in addition to a tandem disc harrow to incorporate the material. In 2002, the tandem disc harrow effectively incorporated the cover crop biomass. In 2004, an articulating spading machine (Celli S.p.A., Forli, Italy) was selected because of its ability to incorporate cover crop biomass without compacting soil at the bottom of the spade's travel. Cover crops were completely killed each year. Plots were disked twice in 2001 and 2004 and once in 2002 before sweetpotato transplanting to ensure sufficient distribution and decomposition of cover crop and a uniform soil bed for planting. Beds were hilled with a ripperbedder several days before sweetpotato transplanting. Slips were planted in beds with the same transplanter as in the organic, no cover crop treatment.

Organic, reduced tillage (Org-RT). This treatment required sweetpotato beds to be established in the fall before cover crop planting. Beds were hilled/formed with a ripper-bedder immediately before fall cover crop seeding (Table 1). The hairy vetch and rye cover crop mixture was seeded to the sides of the beds as well as row middles with a broadcast seeder spreader (PlantMates, Gallatin, TX) and at the same time and rates as the Org-CCI treatment. In Fall 2000, the germination rate of vetch was low on the crest of the hills compared with the furrows, presumably as a result of the inability of the round seeded vetch to remain in place. Therefore, in Fall 2001 and 2003, seeding was followed by seed incorporation with a seeder cultipacker with notched rollers (Brillion Iron Works, Brillion, WI). In May 2001, the cover crop mixture was killed with a flail mower. The flail mower distributed the cover crop material evenly on the plant row and cut the plant residue into relatively small pieces (less than $25 \mathrm{~cm}$ ) that decomposed earlier than desired before sweetpotato harvest. In May 2002 and June 2004, the hairy vetch and rye mixture was killed by rolling a cultipacker to compress the cover crop biomass and thus reduce the rate of decomposition. Sweetpotato slips were transplanted with the same transplanter as other treatments in 2001. In 2002 and 2004, cuttings were transplanted with a subsurface tiller-transplanter (SST-T) (B\&B No-Till, Laurel Fork, VA). This transplanter cut through surface residue with a double disk coulter, loosened soil in the plant bed with a subsurface winged knife, opened a furrow, injected water in the furrow, placed the slip in the furrow, and closed the furrow with weighted press wheels (Morse et al., 1993).

Conventional (Conv). Recommended cultural and pest management practices for 'Beauregard' sweetpotato were followed throughout the season (North Carolina State University and College of Agriculture and Life Sciences, 2005; Wilson et al., 1989). To maintain consistency of preplant tillage events among treatments, Conv plots were tilled with a tandem disc harrow to eliminate weeds in November shortly after cover crops were seeded in the organic treatments (Table 1). In May, overwintering weeds were incorporated with a tandem disc harrow followed by one additional discing $\approx 2$ weeks later. Soil samples collected and submitted for analysis in the fall before cover crop planting tested positive for parasitic nematodes (Meloidogyne spp.) each year; therefore, Conv plots were fumigated 2 weeks before transplanting with 1,3-dichloropropene at 
84.5 $\mathrm{L} \cdot \mathrm{ha}^{-1}$. EPTC was applied 1 week before transplanting in 2001 and 2 weeks before transplanting in 2002 and 2004 at $2.2 \mathrm{~kg} \cdot \mathrm{ha}^{-1}$ for control of annual weeds. This herbicide was mixed with chlorpyrifos at $2.2 \mathrm{~kg} \cdot \mathrm{ha}^{-1}$ for control of soil-dwelling insects, particularly wireworm larvae (Melanotus and Conoderus spp.). In addition, napropramide at 1.1 $\mathrm{kg} \cdot \mathrm{ha}^{-1}$ was applied $1 \mathrm{~d}$ after planting for control of dicot weeds. No additional insecticides or herbicides were applied. Slips were planted with the same transplanter as in the organic, no cover treatment. Ammonium nitrate $\left(\mathrm{NH}_{4} \mathrm{NO}_{3}\right)$ at $56 \mathrm{~kg} \cdot \mathrm{ha}^{-1}$ was surfacebanded and incorporated beside the slips in the row 28 DAT each year.

\section{Data collection}

To minimize variation of mechanical practices as well as the effects of pesticide drift, data were collected in the center eight (of 12) rows and the center $18.3 \mathrm{~m}$ of each plot. A grid of 12 cells was established in the sampling area before cover crop planting so that each cell consisted of $6.1 \mathrm{~m}$ long sections of two adjacent rows or an area $\approx 12.4 \mathrm{~m}^{2}$. Cells and locations within the cells were selected at random.

Stand. Stand counts were performed on each plot 2 to $3 \mathrm{~d}$ after planting by counting all plants in each of the eight data rows. Missing plants were replaced by hand, and a second stand count was performed after replanted plants were established to ensure consistent stand among treatments.

Cover crop biomass and nitrogen. Aboveground biomass was removed from one randomly placed $0.5-\mathrm{m}^{2}$ frame $(102 \mathrm{~cm} \times$ $49 \mathrm{~cm}$ ) perpendicular to the crop row $1 \mathrm{~d}$ before cover crop kill all 3 years. The cover crop mixture was separated by species, ovendried at $60^{\circ} \mathrm{C}$ for $48 \mathrm{~h}$, weighed, ground, and analyzed for total $\mathrm{N}$ and carbon $(\mathrm{C})$ on a Perkin-Elmer $2400 \mathrm{CHN}$ elemental analyzer (Norwalk, CT). Additionally, cover crop biomass remaining in organic reduced tillage plots at sweetpotato harvest was collected, oven-dried at $60{ }^{\circ} \mathrm{C}$, and weighed. Soil was removed from the cover crop biomass by sifting.

Soil sampling. Before cover crop planting, a total of 24 soil cores from each replication were manually collected using a 2-cm (inner radius) soil probe to a depth of $20 \mathrm{~cm}$, combined and mixed in the field, and submitted to NCDA \& CS to identify potential differences in soil nutrient composition among replications. Each year, results among replications were similar; therefore, each replication received similar amendment rates appropriate to each treatment. After sweetpotato transplanting, soil samples were collected four times: 7 DAT, 30 DAT, 60 DAT, and at sweetpotato harvest from a $2-\mathrm{cm}$ (inner radius) soil probe to a $20-\mathrm{cm}$ depth. Fertilizer $\mathrm{N}$ in the Conv system was applied immediately after the 30 DAT sample each year. Soil $\mathrm{N}$ was analyzed for the years 2002 and 2004. Macronutrients $\mathrm{P}, \mathrm{K}$, calcium $(\mathrm{Ca})$, magnesium $(\mathrm{Mg})$, and $\mathrm{pH}$ and base saturation were analyzed and are presented all 3 years.
Soil samples were collected around the main stem of randomly selected sweetpotato plants in a radial area $2.5 \mathrm{~cm}$ away from the main stem to a distance of $13 \mathrm{~cm}$. Twelve cores were composited from each plot, mixed in the field, and the plant material was removed. Soil was separated into two subsamples for soil $\mathrm{N}$ and soil nutrient analysis. Soil subsamples reserved for inorganic $\mathrm{N}$ determination were frozen at less than $5^{\circ} \mathrm{C}$ until processed. Soils were then air-dried in the greenhouse, ground to pass through a 16$\mathrm{mm}$ mesh screen, and extracted with $1 \mathrm{M}$ $\mathrm{KCl}$. Extracts were analyzed for $\mathrm{NH}_{4}$ - and $\mathrm{NO}_{3}-\mathrm{N}$ using a micro-Kjeldahl procedure (Keeney and Nelson, 1986) using injection flow analysis (Lachat Instruments, Milwaukee, WI). The sum of $\mathrm{NH}_{4-}$ and $\mathrm{NO}_{3}-\mathrm{N}$ is presented as total inorganic N. Soil subsamples reserved for analysis of remaining nutrients were submitted to the NCDA \& CS soil analysis laboratory for determination. Nutrients $\mathrm{P}, \mathrm{K}, \mathrm{Ca}, \mathrm{Mg}$ were extracted by Mehlich-3 buffer at a 1:5 soil:solution ratio on a volume basis (Mehlich, 1984). Soil pH and base saturation were also determined. Six soil cores per plot were collected for soil moisture by the same method every 1 to 2 weeks. Gravimetric moisture content was determined using soil oven-dried at $105{ }^{\circ} \mathrm{C}$ for $24 \mathrm{~h}$ and recorded as percent moisture on a dry weight basis.

Sweetpotato leaf tissue nutrients. At 30 and 60 DAT each year, and at sweetpotato harvest in 2004, 24 most recently mature sweetpotato leaves with petioles attached were randomly collected from each plot. Tissue was submitted for nutrient analysis to the NCDA \& CS plant analysis laboratory. Determination of $\mathrm{NO}_{3}$ in petiole sap tissue was by selective ion electrode. Remaining nutrients $[\mathrm{P}, \mathrm{K}, \mathrm{Ca}, \mathrm{Mg}$, manganese $(\mathrm{Mn})$, iron $(\mathrm{Fe})$, aluminum, boron $(\mathrm{B})$, copper $(\mathrm{Cu})$ and zinc (Zn)] were analyzed by inductively coupled plasma emission spectrometry (Optima 3300 DV ICP; PerkinElmer, Shelton, CT).

Sweetpotato vine biomass. To quantify differences in the rate of foliar growth among treatments, three sweetpotato plants per plot were cut at the soil surface $\approx 30,45$, and 60 DAT. Plants were oven-dried at $65{ }^{\circ} \mathrm{C}$ and dry weights recorded.

Yield. Sweetpotato roots were collected from a $6.1-\mathrm{m}$ long section in the center of each of two adjacent rows $\approx 100 \mathrm{~d}$ after planting. Roots were sorted by size according to U.S. Department of Agriculture market grade standards (USDA, 1981) and counted and weighed for each market grade group in the field. Root quality assessments based on degree of insect damage are addressed in another publication in preparation; therefore, for the purpose of this publication, reported yields represent potential rather than marketable yield.

Statistical analysis. All data were subjected to analysis of variance using PROC GLM [Version 8.2; Statistical Analysis Systems (SAS), 2001] to test the main effect of management systems. Management and year were treated as fixed effects and blocks and appropriate error terms as random effects.
For sweetpotato tissue nutrients and biomass, sampling dates were equally spaced and correlations between time points were assumed identical. Soil moisture data represent point in time estimates only and therefore each sample date is independent. For these data, date was considered a subplot factor and year as a whole plot factor in analysis of variance. When significant yearby-treatment interactions existed, data were analyzed and are presented by year. Mean comparisons among management systems were generated using Fisher's protected least significant difference at $P \leq 0.05$. Cover crop, weed, and sweetpotato vine biomass were square root transformed to satisfy assumptions of normality and homogeneity of variances before analysis. Statistical conclusions were derived from transformed data, and back-transformed means derived from transformed data are reported.

\section{Results and Discussion}

Weather. Total precipitation was $12.7 \mathrm{~cm}$ less than the 30-year average during the period of sweetpotato production from June through Oct. 2001 and was not evenly distributed. Temperatures were $1.9^{\circ} \mathrm{C}$ lower on average throughout the season, and in particular, July was $3.2{ }^{\circ} \mathrm{C}$ lower than normal. Heavy rains in May and June combined with cool temperatures contributed to slow water infiltration and evapotranspiration. As a result, standing water remained in the furrows between beds for most of the growing season. Although buffers were managed in ryegrass, they did not impede water movement out of plots. In 2002, monthly precipitation was $37 \%$ lower $(22 \mathrm{~cm})$ than the 30 -year average. Average temperatures in 2002 were near normal with the exception of unusually high temperatures surrounding sweetpotato planting for several days. Therefore, supplemental irrigation $(3.2 \mathrm{~cm})$ was supplied immediately after hand replanting in 2002 to ensure the desired plant stand. In 2004 , average monthly temperature $\left(22^{\circ} \mathrm{C}\right)$ and precipitation $(61 \mathrm{~cm})$ were similar to the 30-year averages throughout the season.

Compost nutrient content. Compost was analyzed for nutrient content and other characteristics before application each year (Table 2). Compost $\mathrm{C}: \mathrm{N}$ ratios were $26: 1$ in 2001, 23:1 in 2002, and 13:1 in 2004. Mature composts with a $\mathrm{C}: \mathrm{N}$ ratio less than $15: 1$ and incorporated in the fall before a summer vegetable crop can mineralize $25 \%$ of the total $\mathrm{N}$ during the cropping season under normal climactic conditions in our area (Baldwin and Greenfield, 2006). PAN can be reduced by an additional $5 \%$ if compost is broadcast and not incorporated or the compost application immediately precedes the crop (Baldwin and Greenfield, 2006). In this experiment, we used an availability coefficient of $15 \%$ in 2001 and $20 \%$ in 2002 and 2004 and adjusted for the potential reduced N mineralization rate in Org-RT by estimating $\mathrm{PAN}$ at $5 \%$ less than remaining organic treatments resulting from lack of soil incorporation. 
Based on these availability coefficients, estimated PAN was as follows: in 2001 was 47 $\mathrm{kg} \cdot \mathrm{ha}^{-1}$ and $\left(15 \%, 49 \mathrm{~kg} \cdot \mathrm{ha}^{-1}\right.$ in 2002 and 2004 (20\%). Because soil N data from 2001 are not available, differences in soil $\mathrm{N}$ resulting from spring versus fall compost application are not known. Management-by-year interactions for soil nutrients $\mathrm{P}, \mathrm{K}, \mathrm{Mg}$, and $\mathrm{Ca}$ imply that nutrient availability was reduced with spring verses fall application but that hypothesis is not supported by data (see discussion under Soil nutrients, PH and base saturation below).

Cover crop biomass and nitrogen availability. Each year, cover crop biomass was similar to or higher than what is typical for eastern North Carolina (Ranells and Wagger, 1997) (Table 3). Cover crop biomass and total $\mathrm{N}$ content was highest in 2001 and declined each year (Table 3). Vetch accounted for $25 \%$ of cover dry weight in Org-RT and Org-CCI each year except in 2004 when vetch was 33\% in Org-CCI. The percent $\mathrm{N}$ in rye averaged $1 \%$ each year, whereas vetch $\mathrm{N}$ averaged $2.4 \%, 3 \%$, and $2.7 \%$ (2001, 2002, and 2004, respectively).

Like compost, mineralization rates of cover crop $\mathrm{N}$ depend on many environmental factors, but some thresholds for $\mathrm{N}$ mineralization/immobilization have been suggested. When $\mathrm{C}: \mathrm{N}$ ratios of cover crops are between 25 and $30: 1$ or if $N$ concentration is less than $16.6 \mathrm{~g} \cdot \mathrm{kg}^{-1} \mathrm{~N}$ (Ranells and Wagger, 1997; Wagger, 1989), $\mathrm{N}$ mineralization will be reduced or delayed. In North Carolina, Ranells and Wagger (1997) predicted N release from surface residue of a terminated cover crop mixture of hairy vetch seed planted at $22 \mathrm{~kg} \cdot \mathrm{ha}^{-1}$ and rye planted at 56 in that study ranged from 82 to $200 \mathrm{~kg} \cdot \mathrm{ha}^{-1} \mathrm{~N}$ with $\mathrm{C}: \mathrm{N}$ ratios of 14 to $21: 1$. The cumulative $\mathrm{N}$ mineralization was $55 \%$ to $58 \%$ of total $\mathrm{N} 4$ weeks after termination, and $75 \%$ to $80 \%$ of total $\mathrm{N} 8$ weeks after termination.

Throughout this study, cover crop C:N ratios ranged from 28:1 to $32: 1$ and were near the theoretical threshold at which $\mathrm{N}$ immo$\mathrm{kg} \cdot \mathrm{ha}^{-1}$. At termination, cover crop $\mathrm{N}$ content

bilization occurs (Table 3). Cover crops were killed eight weeks before planting in 2001 and $\approx 6$ weeks before planting in 2002 and 2004. Plant-available $\mathrm{N}$ during the season was predicted to be $40 \%$ of total $\mathrm{N}$ for incorporated cover crop and 30\% for surface residue (Shipley et al., 1992; Varco et al., 1989) based on the time delay until sweetpotato transplanting and the higher $\mathrm{C}: \mathrm{N}$ ratio of the cover crop. Estimated PAN from cover crops in Org-CCI was $74 \mathrm{~kg} \cdot \mathrm{ha}^{-1}$ in 2001,57 $\mathrm{kg} \cdot \mathrm{ha}^{-1}$ in 2002, and $51 \mathrm{~kg} \cdot \mathrm{ha}^{-1}$ in 2004 , respectively. Estimated inorganic $\mathrm{N}$ available from cover crops in Org-RT was $56 \mathrm{~kg} \cdot \mathrm{ha}^{-1}$ in $2001,43 \mathrm{~kg} \cdot \mathrm{ha}^{-1}$ in 2002 , and $38 \mathrm{~kg} \cdot \mathrm{ha}^{-1}$ in 2004.

A decline in cover crop biomass in each successive experimental planting resulted in a decline of potentially available $\mathrm{N}$ each year. Relative to the $56 \mathrm{~kg} \cdot \mathrm{ha}^{-1}$ of synthetic N fertilizer applied in the conventional system, total estimated PAN contributions from compost plus cover crops were as follows: OrgNCC $(-16 \%,-12.5 \%,-12.5 \%)$, Org-CCI $(+116 \%, \quad+89 \%, \quad+79 \%), \quad$ and Org-RT $(+59 \%,+43 \%,+100 \%)$ for years 2001 , 2002, and 2004, respectively. In summary, organic treatments with applications of both compost and cover crops received more $\mathrm{N}$ than treatments without cover crops, and the potential inorganic $\mathrm{N}$ contributions from organic cover crop treatments was more than anticipated.

Because the goal of selecting a winter cover for weed suppression may lead to a different species than one for nutrient supply or erosion control, growers should identify primary objectives before selecting a cover crop. In this experiment, winter cover crop selection was intended to serve equally as a weed-suppressive mulch in the reduced tillage system and as a source of slow-release $\mathrm{N}$ for sweetpotato in both the cover-incorporated and reduced tillage systems. The hairy vetch and rye cover crop mixture was an appropriate mixture for sweetpotato in terms of dry matter production. However, rye 'Wrens Abruzzi' reached heights in excess

Table 2. Selected characteristics of compost used in organic management systems in 2001, 2002, and 2004.

\begin{tabular}{|c|c|c|c|c|c|c|c|c|c|}
\hline & Total $\mathrm{N}^{\mathrm{z}}$ & $\mathrm{N}$ content ${ }^{\mathrm{y}}$ & $P$ & $\mathrm{~K}$ & $\mathrm{Ca}$ & $\mathrm{Mg}$ & & & Dry matter \\
\hline Yr & $\left(\mathrm{g} \cdot \mathrm{kg}^{-1}\right)$ & $\left(\mathrm{kg} \cdot \mathrm{ha}^{-1}\right)$ & \multicolumn{4}{|c|}{$\left(\mathrm{g} \cdot \mathrm{kg}^{-1}\right)$} & $\mathrm{pH}$ & $\mathrm{C}: \mathrm{N}$ & $(\%)$ \\
\hline 2001 & 16.3 & 326 & 9.9 & 12.6 & 18.0 & 2.7 & 5.9 & 25.9 & 52.7 \\
\hline 2002 & 12.4 & 248 & 5.6 & 4.8 & 27.2 & 2.1 & 6.8 & 23.3 & 60.4 \\
\hline 2004 & 14.3 & 286 & 14.7 & 15.3 & 60.9 & 4.3 & 7.8 & 13.1 & 61.9 \\
\hline
\end{tabular}

${ }^{2}$ Total $\mathrm{N}$ (urea $+\mathrm{NO}_{3}+\mathrm{NH}_{4}$ ) reported on a dry weight basis.

${ }^{\mathrm{y}} \mathrm{N}$ content $=$ total $\mathrm{N}$ present in $20 \mathrm{Mg} \cdot \mathrm{ha}^{-1}$.

Table 3. Hairy vetch and rye dry matter production (biomass), C:N ratio, $\mathrm{N}$ concentration, and $\mathrm{N}$ content in Org-CCI and Org-RT in 2001, 2002, and 2004.

\begin{tabular}{lcccc}
\hline $\mathrm{Yr}$ & $\begin{array}{c}\text { Cover crop } \\
\text { biomass }^{\mathrm{z}}\left(\mathrm{Mg} \cdot \mathrm{ha}^{-1}\right)\end{array}$ & $\mathrm{C}: \mathrm{N}$ ratio & $\mathrm{N} \mathrm{concn}\left(\mathrm{g} \cdot \mathrm{kg}^{-1}\right)$ & $\begin{array}{r}\mathrm{N} \text { content } \\
\left(\mathrm{kg} \cdot \mathrm{ha} \mathrm{t}^{\mathrm{x}}\right.\end{array}$ \\
\hline 2001 & $13.62 \mathrm{a}^{\mathrm{w}}$ & $32.09 \mathrm{a}$ & $13.7 \mathrm{a}$ & $186.4 \mathrm{a}$ \\
2002 & $9.78 \mathrm{~b}$ & $30.24 \mathrm{a}$ & $14.9 \mathrm{a}$ & $142.4 \mathrm{~b}$ \\
2004 & $8.02 \mathrm{c}$ & $28.13 \mathrm{a}$ & $16.4 \mathrm{a}$ & $127.9 \mathrm{~b}$ \\
\hline
\end{tabular}

${ }^{\mathrm{z}}$ Cover crop biomass and $\mathrm{N}$ content were square root transformed for homogeniety of variance.

${ }^{\mathrm{y}} \mathrm{N}$ concentration is the sum of inorganic and organic $\mathrm{N}$.

${ }^{\mathrm{x}}$ Total nitrogen present in the application rate (biomass).

wMean separation within column and year by Fisher's protected least significant difference $(P \leq 0.05)$.

Org- $\mathrm{CCI}=$ organically managed, cover crop incorporated; Org-RT = organically managed, reduced tillage. of $1.8 \mathrm{~m}$ each year and was difficult to incorporate in Org-CCI. An earlier-maturing variety with reduced stature such as 'Wheeler' may facilitate mechanical operations and provide more chemical compound for weed suppression (Reberg-Horton et al., 2005).

Soil moisture. Sample dates varied each year relative to crop development; therefore, data were analyzed by year in PROC GLM (SAS Version 8). To test for the main effect of sample date, date was treated as a fixed effect, and treatment nested in date was used to test for date-by-treatment interactions within each year. Sample date and treatment interactions were significant in 2001 and $2002(P<0.01)$ (data not shown). Therefore, soil moisture data are presented by year and date.

Soil moisture differences among treatments occurred sporadically throughout the experiment (Table 4). The Wickam soil series has an available water capacity that ranges from $11 \%$ to $15 \%$ to a depth of $36 \mathrm{~cm}$ (U.S. Department of Agriculture and the Soil Conservation Service, 1974). Soil moisture levels in 2001 and 2004 generally were within or exceeded this range, but soil moisture in 2002 exceeded $11 \%$ at only two sampling dates and treatments: Org-RT (35 DAT and 69 DAT) and Conv (69 DAT).

In 2001, soil moisture in Org-CCI was higher than Org-RT on three occasions and higher than Org-NCC on two. Abundant cover crop biomass incorporated before planting (Table 3 ) may have facilitated soil moisture retention in Org-CCI compared with other systems. In 2002, soil moisture was limiting in the first half of the growing season, and the Conv managed system generally had less moisture than organic systems receiving cover crops. In particular, Conv had $61 \%$ less moisture than Org-RT at 35 DAT (Table 4) attributable in part to shallow tillage associated with mechanical weed control and abundant sweetpotato foliar biomass in Conv (Fig. 1). Six days later, soil moisture levels reached a seasonal low, ranging from $4.2 \%$ to $5.8 \%$ among treatments. In 2002, soil moisture means in organically managed treatments receiving cover crops were occasionally higher than remaining treatments during the dry conditions. In 2004, soil moisture was different among systems only once with Org-RT having the highest soil moisture at 31 DAT.

Soil nitrogen. Soil N was influenced by a year, sample date, and treatment interaction (data not shown); therefore, data are presented by year and sample date (Fig. 2). Data were averaged over sample dates and year and contrast statements were used to compare management (Conv versus all three organic systems; $P<0.05$ ), cover crops (Org-NCC versus two organic systems with cover crops; $P=0.01$ ), and tillage (Org-CCI versus OrgRT; $P=0.0001)$ (data not shown)

In 2002, dry conditions punctuated by irregular precipitation influenced soil $\mathrm{N}$ differences among management systems. Soil $\mathrm{N}$ was higher in Org-CCI and Org-NCC 
Table 4. Gravimetric soil moisture (\%) in management systems at six sample dates indicated here as days after transplanting (DAT) in 2001, 2002, and 2004.

\begin{tabular}{lcccccc}
\hline & \multicolumn{5}{c}{ Soil moisture $(\%)$} \\
\cline { 2 - 7 } Management & Date 1 & Date 2 & Date 3 & Date 4 & Date 5 & Date 6 \\
\hline 2001 & 14 DAT & 45 DAT & 58 DAT & 68 DAT & 76 DAT & 103 DAT \\
\cline { 2 - 7 } Organic-NCC & $14.1 \mathrm{~b}^{\mathrm{z}}$ & $17.7 \mathrm{~b}$ & $15.7 \mathrm{a}$ & $18.3 \mathrm{a}$ & $16.6 \mathrm{a}$ & $15.6 \mathrm{a}$ \\
Organic-CCI & $16.0 \mathrm{a}$ & $20.7 \mathrm{a}$ & $16.3 \mathrm{a}$ & $19.0 \mathrm{a}$ & $18.1 \mathrm{a}$ & $16.4 \mathrm{a}$ \\
Organic-RT & $13.6 \mathrm{~b}$ & $16.9 \mathrm{~b}$ & $13.6 \mathrm{a}$ & $15.1 \mathrm{~b}$ & $14.7 \mathrm{a}$ & $14.8 \mathrm{a}$ \\
Conventional & $14.4 \mathrm{ab}$ & $18.4 \mathrm{ab}$ & $14.9 \mathrm{a}$ & $17.6 \mathrm{ab}$ & $15.7 \mathrm{a}$ & $14.5 \mathrm{a}$ \\
2002 & $8 \mathrm{DAT}$ & $35 \mathrm{DAT}$ & $41 \mathrm{DAT}$ & $51 \mathrm{DAT}$ & $69 \mathrm{DAT}$ & $105 \mathrm{DAT}$ \\
Organic-NCC & $10.0 \mathrm{a}$ & $7.5 \mathrm{bc}$ & $4.4 \mathrm{a}$ & $6.2 \mathrm{ab}$ & $10.6 \mathrm{a}$ & $9.1 \mathrm{a}$ \\
Organic-CCI & $10.9 \mathrm{a}$ & $8.8 \mathrm{~b}$ & $5.0 \mathrm{a}$ & $6.6 \mathrm{ab}$ & $10.6 \mathrm{a}$ & $10.8 \mathrm{a}$ \\
Organic-RT & $9.9 \mathrm{~A}$ & $11.3 \mathrm{a}$ & $5.8 \mathrm{a}$ & $7.2 \mathrm{a}$ & $11.3 \mathrm{a}$ & $10.9 \mathrm{a}$ \\
Conventional & $9.0 \mathrm{a}$ & $6.9 \mathrm{c}$ & $4.2 \mathrm{a}$ & $5.2 \mathrm{~b}$ & $11.9 \mathrm{a}$ & $10.3 \mathrm{a}$ \\
2004 & & & & & & \\
Organic-NCC & $9.7 \mathrm{a}$ & $11.4 \mathrm{~b}$ & $9.8 \mathrm{a}$ & $14.8 \mathrm{a}$ & $14.1 \mathrm{a}$ & $15.0 \mathrm{a}$ \\
Organic-CCI & $10.1 \mathrm{a}$ & $13.1 \mathrm{ab}$ & $10.5 \mathrm{a}$ & $16.3 \mathrm{a}$ & $15.9 \mathrm{a}$ & $15.9 \mathrm{a}$ \\
Organic-RT & $11.4 \mathrm{a}$ & $14.0 \mathrm{a}$ & $10.5 \mathrm{a}$ & $14.7 \mathrm{a}$ & $14.2 \mathrm{a}$ & $14.9 \mathrm{a}$ \\
Conventional & $10.4 \mathrm{a}$ & $12.6 \mathrm{ab}$ & $10.3 \mathrm{a}$ & $15.4 \mathrm{a}$ & $14.9 \mathrm{a}$ & $16.9 \mathrm{a}$ \\
\hline
\end{tabular}

${ }^{2}$ Mean separation within column and year by Fisher's protected LSD $(P \leq 0.05)$.

Org-NCC = organically managed, no cover crop; Org-CCI = organically managed, cover crop incorporated; Org-RT = organically managed, reduced tillage.

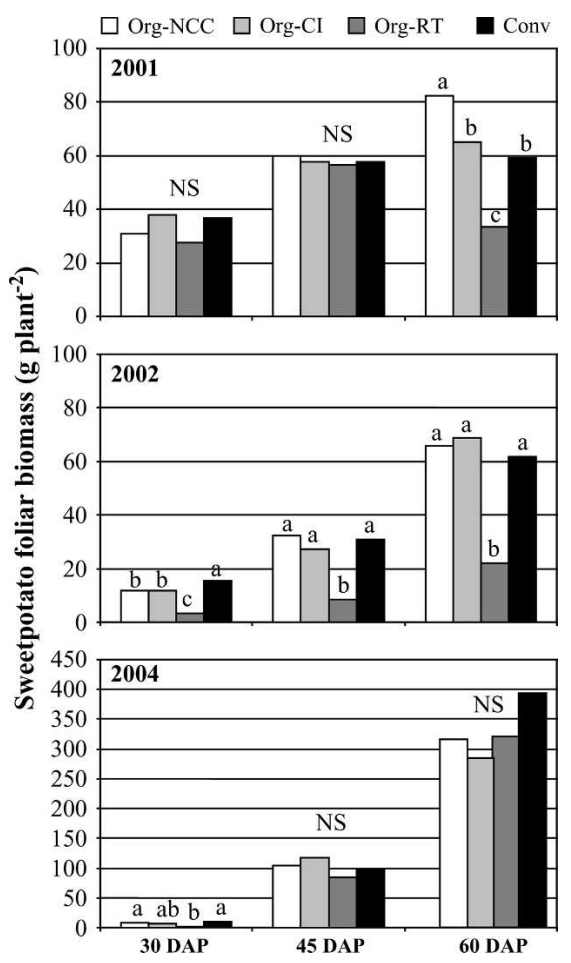

Fig. 1. Seasonal sweetpotato foliar biomass $(\mathrm{g} /$ plant) at 30,45 , and $60 \mathrm{~d}$ after transplanting (DAT) in 2001, 2002, and 2004.

compared with Org-RT during the first 4 weeks of the season (Fig. 2). At 7 DAT, soil $\mathrm{N}$ was highest in Org-CCI, intermediate in Org-NCC and Conv, and lowest in Org-RT. Soil $\mathrm{N}$ was likely retained in the upper $20 \mathrm{~cm}$ of the soil attributable in part to dry conditions. At 30 DAT, soil $\mathrm{N}$ in the Org-CCI system was considerably higher than remaining systems. Precipitation several days before the 30 DAT sampling date may have facilitated decomposition of the cover crop in Org$\mathrm{CCI}$ and consequent rapid mineralization of soil N. The addition of compost in Org-NCC provided additional $\mathrm{N}$ over the conventionally managed system after the first week of planting. Significant plant N demands concurrent with the 60 DAT sampling date most likely contributed to the decline in soil $\mathrm{N}$ at 60 DAT in all systems. By harvest (100 DAT), only slight differences among systems were observed. In 2004, soil N was similar among systems at each planting date. Favorable environmental conditions, including sufficient soil moisture, moderated mineralization of organic $\mathrm{N}$ resulting in soil $\mathrm{N}$ levels that were consistent with the conventionally managed system.

The occasional periods of dry soil conditions were particularly significant in terms of the soil biology. Organic systems rely on soil microbial transformation of $\mathrm{N}$ to plantavailable forms, and soil biological activity is influenced by soil moisture and temperature. Soil moisture levels from $50 \%$ to $70 \%$ of water-holding capacity are associated with maximum aerobic microbial activity (Linn and Doran, 1984), but other studies report the range could include 100\% water-holding capacity (Goncalves and Carlyle, 1994; Kabba and Aulakh, 2004). Low soil moisture (15 bars) inhibits activity of nitrifying bacteria, reducing substrate diffusion and intracellular water potential and thus reducing enzyme activity (Stark and Firestone, 1995) and increasing $\mathrm{N}$ immobilization (Senesvirante et al., 1998).

The temperature coefficient $\left(\mathrm{Q}_{10}\right)$ of organic matter decomposition is 2 when substrate temperatures range from 5 to 35 ${ }^{\circ} \mathrm{C}$ (Kätterer et al., 1998). Transformation of ammonium $\left(\mathrm{NH}_{4}{ }^{+}\right)$to nitrate $\left(\mathrm{NO}_{3}{ }^{-}\right)$ increased linearly with temperature ranging from $5{ }^{\circ} \mathrm{C}$ (immobilization of $\mathrm{NH}_{4}^{+}$) to higher than $20{ }^{\circ} \mathrm{C}$ (oxidation to $\mathrm{NO}_{3}^{-}$) in a recent study (Hoyle et al., 2006). In this experiment, soil temperature ranged from 11 to $30{ }^{\circ} \mathrm{C}$ (data not shown) and soil moisture ranged from $4.2 \%$ to $16.9 \%$, indicating that $\mathrm{N}$ transformations likely occurred at different rates during the course of the season depending on environmental conditions.

Nitrogen management is important to optimize yields of sweetpotato. $\mathrm{N}$ deficiencies early in the season may delay foliar development, thus delaying root carbohydrate acquisition (Villagarcia et al., 1998), whereas excess $\mathrm{N}$ is subject to leaching and can reduce yield at the expense of additional foliar growth (Hammett et al., 1984; Marti and Mills, 2002; Villagarcia et al., 1998). Nitrogen demands vary greatly among cultivars, and yield response to fertilizer $\mathrm{N}$ uptake is closely associated with climactic factors, making prediction difficult (Mascianica et al., 1985; Phillips et al., 2005). Soil $\mathrm{NO}_{3}$ $\mathrm{N}$ levels greater than $37 \mu \mathrm{g} \cdot \mathrm{g}^{-1} \mathrm{~N}$ soil at 29 DAT were suggested as adequate for 'Painter' and 'Centennial' sweetpotato nutrition; however, the model predicted that recommended rates of 56 to $84 \mathrm{~kg} \cdot \mathrm{ha}^{-1} \mathrm{~N}$ may be excessive from an economic standpoint if precipitation during the 6 months before sweetpotato planting was less than $80 \mathrm{~cm}$ (Mascianica et al., 1985). In a Virginia field trial to identify optimum fertilizer $\mathrm{N}$ rate and timing of application for 'Beauregard' sweetpotato, Phillips et al. (2005) observed that under conditions of normal seasonal precipitation (390 $\mathrm{mm}$ from June to September), only $28 \mathrm{~kg} \cdot \mathrm{ha}^{-1}$ of fertilizer $\mathrm{N}$ was necessary for optimum yields. When precipitation was above average, additional fertilizer $\mathrm{N}$ was necessary and the optimum rate increased to $58 \mathrm{~kg} \cdot \mathrm{ha}^{-1} \mathrm{~N}$ (Phillips et al., 2005; Schultheis and Jester, 2002). Highest yields were observed when fertilizer $\mathrm{N}$ was applied 2 to 3 weeks after planting compared with $\mathrm{N}$ supplied before planting or 4 to 5 weeks after planting. These observations suggest the $\mathrm{N}$ requirement for 'Beauregard' is less than recommendations for previously grown varieties (Wilson et al., 1989) and that $\mathrm{N}$ demand may occur earlier in the season than previously thought.

Soil nutrients, $\mathrm{pH}$, and base saturation. Management-by-year interactions influenced soil $\mathrm{P}, \mathrm{K}, \mathrm{Ca}$, and $\mathrm{Mg}$ concentrations, $\mathrm{pH}$, and base saturation (Table 5). Therefore, data were averaged over sampling dates and analyzed by year (Table 5). These same soil parameters were also influenced by a dateby-year interaction; therefore, data were also analyzed by year and date. However, no consistent trends were evident from this analysis and differences were most likely the result of a complex of environmental and management factors (data not shown).

In most cases, soil nutrient reserves were higher in organically managed systems compared with the conventional system likely resulting from nutrients supplied through compost as well as cover crops (Table 5). This difference can be attributed to the additional $\mathrm{P}$ provided by compost. The Mehlich-3 extraction used in analysis can overestimate the amount of soil $\mathrm{P}$ that might be available for crop uptake. However, the P content present in all treatments is clearly higher than sweetpotato requirements (Nicholaides et al., 1985). Cover crops in 


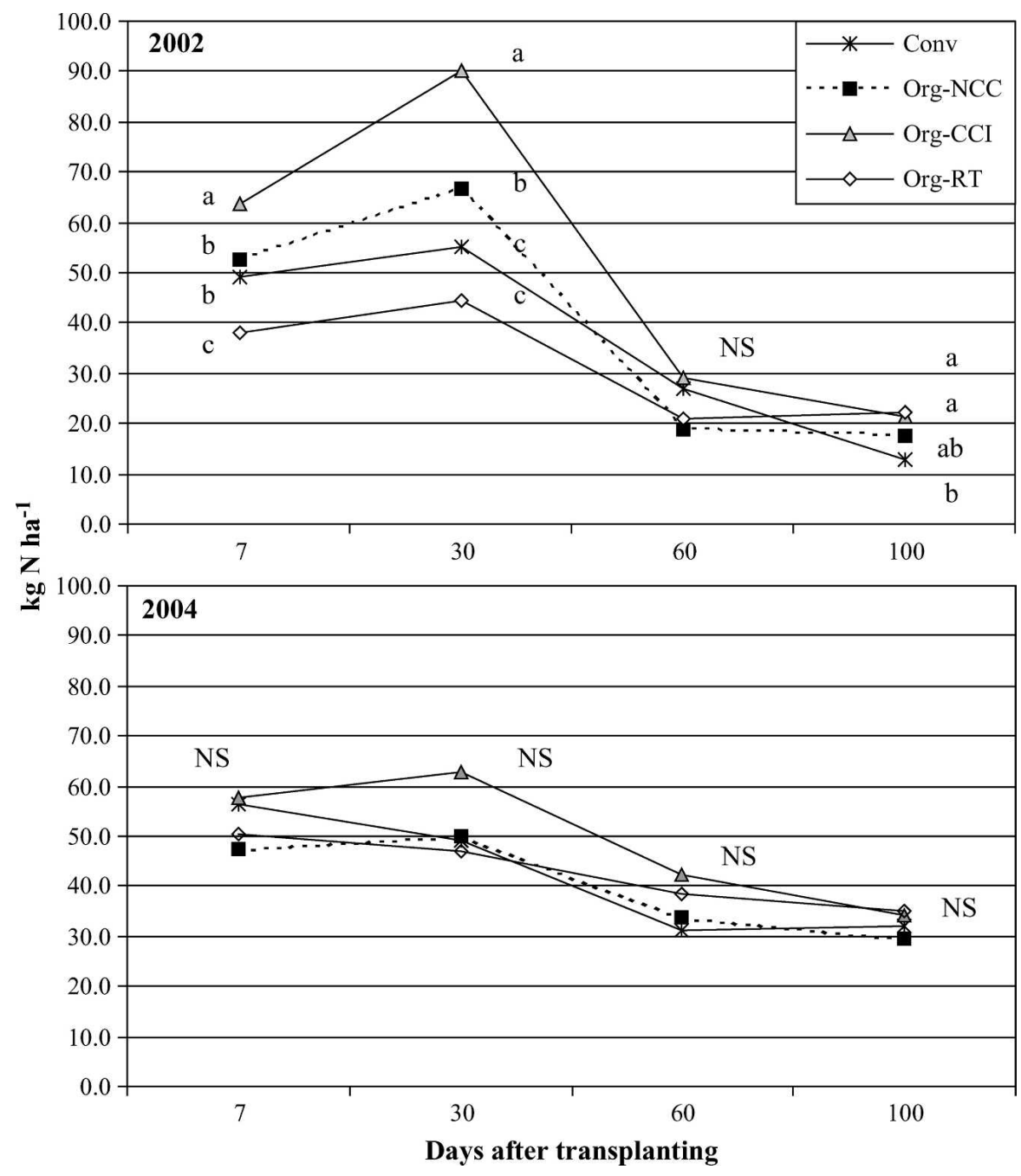

Fig. 2. Soil total inorganic nitrogen $\left(\mathrm{NO}_{3}+\mathrm{NH}_{4}\right)$ sampled to a depth of $20 \mathrm{~cm}$ in management systems at 7, 30, and $60 \mathrm{~d}$ after transplanting and sweetpotato harvest averaged over 2002 and 2004. Mean separation within year and sample date by Fisher's protected least significant difference at $P \leq 0.05$.

organic systems contributed to greater soil $\mathrm{P}$ than Org-NCC in 2001 and 2002, likely as a result of soil $\mathrm{P}$ utilization by the extensive root system of rye. In 2002, a dry year, means of soil $\mathrm{P}$ were higher in all systems compared with 2001 and 2004 (Table 5). Soil P reserves in the fall before the production season were higher at the 2002 location $(522 \mathrm{ppm} \pm 128)$ than $2001(273 \mathrm{ppm} \pm 86)$ or 2004 (206 ppm $\pm 43)$. In addition, inadequate soil moisture in 2002 may have reduced $P$ uptake by sweetpotato, resulting in higher soil $P$ reserves.

Potassium is critical to root expansion, and the recommended $\mathrm{N}: \mathrm{K}$ ratio for sweetpotato is $1: 1.5$ to $1: 2.0$ (International Fertilizer Industry Association, 1992). In this experiment, ratios of $\mathrm{N}: \mathrm{K}$ were higher than recommended. Yield response in sweetpotato has been associated with $\mathrm{K}$ uptake for some cultivars. Mascianica et al. (1985) evaluated 'Centennial' and 'Painter' sweetpotato to obtain sweetpotato leaf tissue and soil $\mathrm{N}$ concentrations to predict yield response to $\mathrm{N}$ fertilization. They modeled soil $\mathrm{NO}_{3}-\mathrm{N}$ sampled at a depth of $15 \mathrm{~cm}$ to relative yield at 29 DAT and reported a minimum of 74 $\mathrm{kg} \cdot \mathrm{ha}^{-1}$ was required by those cultivars for adequate $\mathrm{N}$ nutrition. 'Centennial' had a positive yield response to $\mathrm{N}$ rates as high as $112 \mathrm{~kg} \cdot \mathrm{ha}^{-1}$ but only when ample $\mathrm{K}$ was provided (up to $112 \mathrm{~kg} \cdot \mathrm{ha}^{-1}$ ) (Marti and Mills, 2002). Similar observations were made by Marti and Mills (2002) and Purcell et al. (1982) who reported a yield increase with an increase in K rate for 'Centennial', but not 'Jewel'. The importance of fertilizer K on $\mathrm{N}$ uptake and yield in 'Beauregard' has not been fully explored. In this experiment, soil $\mathrm{K}$ was consistently greatest in Org-CCI and lowest in the conventionally managed system. Over the course of the growing season, Org-CCI had 126,86 , and $73 \mathrm{~kg} \cdot \mathrm{ha}^{-1}$ more soil $\mathrm{K}$ than Conv in 2001, 2002, and 2004, respectively (Table 5). As discussed previously, soil $\mathrm{N}$ was higher in Org-CCI than Conv at several sample dates in 2002; however, the increase in soil $\mathrm{N}$ and $\mathrm{K}$ in Org-CCI did not translate into an increase in sweetpotato $\mathrm{N}$ or $\mathrm{K}$ uptake at 30 DAT (Table 6) or yield (Table 7) compared with Conv in 2002.

In 2001, soil $\mathrm{Ca}$ and $\mathrm{Mg}$ means in all systems were higher than other years and may reflect inherent soil fertility associated with the site resulting from previous man- agement as pasture (Table 5). Soil Ca was higher in organically managed systems each year, whereas soil $\mathrm{Mg}$ was higher in organically managed systems in 2001 only. Base saturation, the percentage of the cation exchange capacity occupied by $\mathrm{K}, \mathrm{Ca}$, and $\mathrm{Mg}$ followed trends similar to $\mathrm{pH}$ in 2002, with some variations in 2001 and 2004. Compost with and without cover crops improved base saturation because cation retention in organically managed systems exceeded the conventionally managed system each year.

$\mathrm{A} \mathrm{pH}$ of 5.6 to 6.8 is a typical range for crops in southeastern soils. With the exception of a reduction in $\mathrm{pH}$ in Conv in 2004, $\mathrm{pH}$ ranged from 5.5 to 6.2 over the course of this experiment (Table 5). The addition of organic amendments contributed to an increase in $\mathrm{pH}$ compared with the conventionally managed system all 3 years. The $\mathrm{pH}$ in Org-NCC was higher than other systems in 2001 and higher in Org-NCC and Org-RT in 2002 and 2004.

Sweetpotato tissue nutrients. All nutrients were influenced by a date-by-year interaction except $\mathrm{P}$, which varied by year and date main effects (Table 6). Additionally, nutrients were influenced by a managementby-year interaction or a management main effect. For consistency, all nutrients were analyzed by year and date (Table 6). Sweetpotato nutrient sufficiency ranges have not been formally established for 'Beauregard'; therefore, sufficiency ranges used in this report were general recommendations for sweetpotato provided by NCDA \& CS (S. Casteel, personal communication, 2005).

Differences in soil nutrient concentration among management systems within a specific year were generally not reflected in differences in sweetpotato tissue nutrient concentrations. Concentrations of leaf tissue $\mathrm{N}, \mathrm{P}$, and $\mathrm{K}$ were different among management systems only in 2004 and only at the 60 DAT sampling date (Table 6). In lowinput systems, organic soil amendments have resulted in a decline of $\mathrm{N}$ concentration in plant tissue (Drinkwater et al., 1995; Scow et al., 1994); however, in this experiment, $\mathrm{N}$ concentrations in organically managed sweetpotato tissue were equal to the conventional system in 2001 and 2002 and in one treatment higher than the conventional system in 2004 (Table 6). In 2001, N concentrations exceeded the $\mathrm{N}$ sufficiency range defined by NCDA $(3.2 \%$ to $4.0 \%)$ and were ranked "high" or in "excess" according to NCDA guidelines. In 2002 and 2004, N concentrations were within sufficiency ranges for all systems and were similar to those observed for 'Jewel' by Nicholaides et al. (1985) and Hammett et al. (1984).

Despite differences in soil $\mathrm{P}$ among production systems (Table 5), $\mathrm{P}$ uptake was similar among all systems in 2001 (Table 6). In 2002, a reduction in P uptake by plants in Org-RT at 30 DAT may have been the result of a reduction in $\mathrm{P}$ availability from cover crop surface residue. Dry conditions 
Table 5. Analysis of variance combined over 3 years $(2001,2002$, and 2004) and protected LSDs averaged over sampling dates in management systems by year for soil nutrient content $\left(\mathrm{kg} \cdot \mathrm{ha}^{-1}\right), \mathrm{pH}$, and base saturation (Basesat) (\%).

\begin{tabular}{|c|c|c|c|c|c|c|c|}
\hline \multirow[b]{2}{*}{ Management } & & $\mathrm{P}$ & $\mathrm{K}$ & $\mathrm{Ca}$ & $\mathrm{Mg}$ & \multirow[b]{2}{*}{$\mathrm{pH}$} & \multirow{2}{*}{$\begin{array}{c}\text { Basesat }^{2} \\
(\%)\end{array}$} \\
\hline & & \multicolumn{4}{|c|}{ Nutrient content $\left(\mathrm{kg} \cdot \mathrm{ha}^{-1}\right)$} & & \\
\hline \multicolumn{8}{|l|}{2001} \\
\hline Organic-NCC & & $734.1 \mathrm{~b}^{\mathrm{y}}$ & $411.8 \mathrm{~b}$ & $21,850.5 \mathrm{a}$ & $5,208.5 \mathrm{a}$ & $6.0 \mathrm{a}$ & $85.5 \mathrm{a}$ \\
\hline Organic-CCI & & $802.4 \mathrm{a}$ & 492.9 a & $21,766.7$ a & $5,086.9 \mathrm{~b}$ & $5.9 \mathrm{~b}$ & $84.2 \mathrm{ab}$ \\
\hline Organic-RT & & $831.8 \mathrm{a}$ & $466.4 \mathrm{a}$ & $22,016.7 \mathrm{a}$ & $5,005.9 \mathrm{~b}$ & $5.9 \mathrm{~b}$ & $83.5 \mathrm{~b}$ \\
\hline Conventional & & $513.2 \mathrm{c}$ & $366.7 \mathrm{c}$ & $20,983.3 \mathrm{~b}$ & $4,813.3 \mathrm{c}$ & $5.8 \mathrm{~b}$ & $81.2 \mathrm{c}$ \\
\hline CV (\%) & & 11.5 & 12.9 & 3.5 & 4.1 & 2.6 & 3.2 \\
\hline \multicolumn{8}{|l|}{2002} \\
\hline Organic-NCC & & $1,258.4 \mathrm{c}$ & $358.4 \mathrm{~b}$ & $1,423.7 \mathrm{~b}$ & $333.4 \mathrm{a}$ & $6.2 \mathrm{a}$ & 84.9 a \\
\hline Organic-CCI & & $1,279.4 \mathrm{c}$ & $389.0 \mathrm{a}$ & $1,459.7 \mathrm{ab}$ & $390.0 \mathrm{a}$ & $6.0 \mathrm{~b}$ & $83.4 \mathrm{~b}$ \\
\hline Organic-RT & & $1,369.9 \mathrm{a}$ & $355.8 \mathrm{~b}$ & $1,497.3 \mathrm{a}$ & $329.6 \mathrm{a}$ & $6.2 \mathrm{a}$ & $84.5 \mathrm{a}$ \\
\hline Conventional & & $1,329.1 \mathrm{~b}$ & $302.7 \mathrm{c}$ & $1,202.5 \mathrm{c}$ & $315.9 \mathrm{a}$ & $5.9 \mathrm{c}$ & $80.1 \mathrm{c}$ \\
\hline CV (\%) & & 4.5 & 10.1 & 5.8 & 10.8 & 1.5 & 2.3 \\
\hline \multicolumn{8}{|l|}{2004} \\
\hline Organic-NCC & & $701.7 \mathrm{a}$ & $365.3 \mathrm{a}$ & $1,413.1 \mathrm{a}$ & $205.6 \mathrm{a}$ & $5.6 \mathrm{ab}$ & $83.0 \mathrm{a}$ \\
\hline Organic-CCI & & $663.6 \mathrm{a}$ & 387.9 a & $1,421.6 \mathrm{a}$ & $210.5 \mathrm{a}$ & $5.5 \mathrm{~b}$ & $82.3 \mathrm{ab}$ \\
\hline Organic-RT & & $700.4 \mathrm{a}$ & $380.1 \mathrm{a}$ & $1,449.0 \mathrm{a}$ & $214.5 \mathrm{a}$ & $5.6 \mathrm{a}$ & $81.8 \mathrm{~b}$ \\
\hline Conventional & & $575.7 \mathrm{~b}$ & $314.7 \mathrm{~b}$ & $1,069.6 \mathrm{~b}$ & $204.8 \mathrm{a}$ & $5.3 \mathrm{c}$ & $76.0 \mathrm{c}$ \\
\hline CV $(\%)$ & & 10.6 & $\begin{array}{c}14.8 \\
\text { Statist }\end{array}$ & 8.8 & 9.3 & 1.3 & 2.5 \\
\hline Source of variation & $\mathrm{df}$ & $\mathrm{P}$ & $\mathrm{K}$ & $\mathrm{Ca}$ & $\mathrm{Mg}$ & $\mathrm{pH}$ & Basesat \\
\hline Year $(\mathrm{Y})$ & 2 & **** & NS & $* * *$ & $* * * *$ & ${ }_{* * * *}$ & NS \\
\hline Error a & 15 & - & - & - & - & - & - \\
\hline Date (D) & 3 & *** & **** & NS & ** & *** & *** \\
\hline $\mathrm{D} * \mathrm{Y}$ & 6 & ** & **** & ** & ** & **** & *** \\
\hline Error b & 45 & - & - & - & - & - & - \\
\hline Management (M) & 3 & *** & *** & **** & *** & **** & $* * *$ \\
\hline$M * D$ & 9 & NS & NS & NS & NS & NS & **** \\
\hline $\mathrm{M}^{*} \mathrm{Y}$ & 6 & **** & $*$ & $*$ & *** & $*$ & * \\
\hline $\mathrm{M}^{*} \mathrm{D}^{*} \mathrm{Y}$ & 18 & NS & NS & NS & NS & NS & NS \\
\hline Error c & 180 & - & - & - & - & - & - \\
\hline
\end{tabular}

${ }^{\mathrm{z}}$ Base saturation is the percentage of the cation exchange capacity occupied by the basic cations calcium, magnesium, and potassium.

${ }^{y}$ Mean separation within column and year by Fisher's protected LSD $(P \leq 0.05)$.

Ns, *, **, **** Nonsignificant or significant at $P \leq 0.05,0.01$, or 0.0001 , respectively. Org-CCI, organically managed, cover crop incorporated; Org-RT, organically managed, reduced tillage. most likely reduced soil microbial activity and consequent $\mathrm{P}$ availability in the soil. In 2004, P concentration in sweetpotato tissue was greatest in Org-CCI compared with other systems. The frequent increase in soil $\mathrm{P}, \mathrm{K}$, and $\mathrm{Ca}$ concentrations in Org-RT systems compared with Conv most likely reflects the reduction in foliar biomass production in Org-RT (Fig. 1).

Potassium concentrations were within or exceeded sufficiency ranges $(2.5 \%$ to $3.5 \%)$ in all systems each year. In 2004, K concentrations were again greatest in Org-CCI compared with remaining systems and lowest in Org-NCC and Conv. Nicholaides et al. (1985) observed an increase in K uptake by 'Jewel' and 'Centennial' sweetpotato tissue with an increase in fertilizer $\mathrm{K}$ application. The authors reported optimum yields for those cultivars were correlated with midseason leaf $\mathrm{K}$ concentrations that ranged between 38.1 and $42.9 \mathrm{~g} \cdot \mathrm{kg}^{-1}$ or $3.8 \%$ to $4.3 \%$. Midseason (60 DAT) tissue K concentrations in this experiment were less than $3 \%$ in 2002 , providing some indication of reduced yields overall that year. Although soil $\mathrm{Ca}$ and $\mathrm{Mg}$ concentrations were considerably high in 2001 (Table 5), sweetpotato tissue $\mathrm{Ca}$ and $\mathrm{Mg}$ concentrations were generally sufficient, if not low (Table 6). Differences among systems were observed only in 2002. An increase in $\mathrm{Ca}$ and $\mathrm{Mg}$ in sweetpotato tissue was observed for Org-RT at 30 DAT and may be a reflection of reduced foliar biomass and yield in that system (Fig. 1). Concurrently, a decrease in tissue $P$ was observed. Phosphorus can be limiting in

Table 6. Analysis of variance and protected LSDs by sampling date indicated here as 30 and $60 \mathrm{~d}$ after transplanting (DAT) and year (2001, 2002, and 2004) of sweetpotato leaf nutrient concentrations

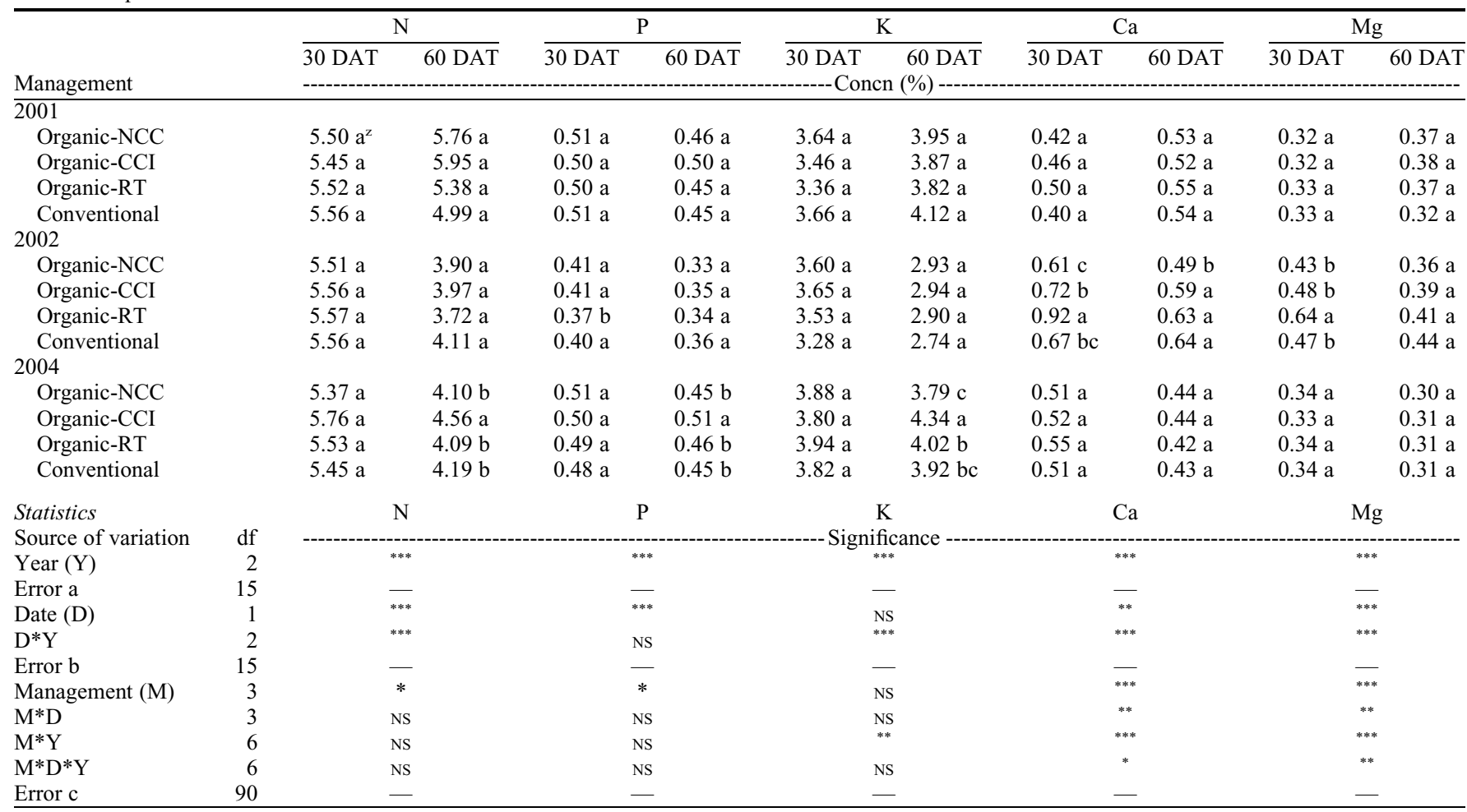

${ }^{\mathrm{z}}$ Mean separation within column and year by Fisher's protected least significant difference (LSD) $(P \leq 0.05)$.

Ns, ****,****Nonsignificant or significant at $P \leq 0.05,0.01$, or 0.0001 , respectively.

Org-NCC = organically managed, no cover crop; Org-CCI = organically managed, cover crop incorporated; Org-RT = organically managed, reduced tillage. 
Table 7. Analysis of variance and protected LSDS of sweetpotato yield by market grade in management systems in 2001, 2002, and 2004.

\begin{tabular}{|c|c|c|c|c|c|c|}
\hline \multirow{2}{*}{ Management } & & Total $^{\mathrm{z}}$ & Jumbos & Canner & No. 1s & No. 1s $(\%)$ \\
\hline & & \multicolumn{5}{|c|}{ 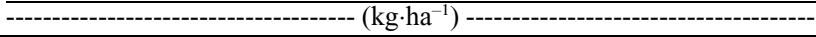 } \\
\hline \multicolumn{7}{|l|}{2001} \\
\hline Organic-NCC & & $15,447.0 \mathrm{a}^{\mathrm{y}}$ & $40.3 \mathrm{a}$ & $5,692.7 \mathrm{ab}$ & $9,457.0 \mathrm{a}$ & $61.5 \mathrm{ab}$ \\
\hline Organic-CCI & & $15,404.8 \mathrm{a}$ & $67.2 \mathrm{a}$ & $4,944.5 \mathrm{~b}$ & $10,008.0 \mathrm{a}$ & $64.5 \mathrm{ab}$ \\
\hline Organic-RT & & $14,284.6 \mathrm{a}$ & $12.3 \mathrm{a}$ & $7,600.5 \mathrm{a}$ & $6,404.8 \mathrm{a}$ & $44.5 \mathrm{c}$ \\
\hline Conventional & & $15,468.1 \mathrm{a}$ & $15.7 \mathrm{a}$ & $7,574.2 \mathrm{a}$ & $7,679.0 \mathrm{a}$ & $50.0 \mathrm{bc}$ \\
\hline $\mathrm{CV}(\%)$ & & 12.4 & 230.6 & 14.2 & 18.9 & 20.3 \\
\hline \multicolumn{7}{|l|}{2002} \\
\hline Organic-NCC & & $21,774.0 \mathrm{a}$ & $665.1 \mathrm{a}$ & $8,139.1 \mathrm{a}$ & $30,944.3 \mathrm{a}$ & $70.8 \mathrm{a}$ \\
\hline Organic-CCI & & $19,215.5 \mathrm{a}$ & $619.9 \mathrm{a}$ & $7,678.1 \mathrm{a}$ & $26,680.0 \mathrm{a}$ & $73.6 \mathrm{a}$ \\
\hline Organic-RT & & $4,947.7 \mathrm{~b}$ & $85.2 \mathrm{a}$ & $4,332.3 \mathrm{a}$ & $9,862.5 \mathrm{~b}$ & $47.9 \mathrm{~b}$ \\
\hline Conventional & & $16,718.5 \mathrm{a}$ & $174.3 \mathrm{a}$ & $7,545.5 \mathrm{a}$ & $24,831.5 \mathrm{a}$ & $67.2 \mathrm{a}$ \\
\hline CV $(\%)$ & & 14.0 & 94.6 & 18.5 & 16.6 & 19.0 \\
\hline \multicolumn{7}{|l|}{2004} \\
\hline Organic-NCC & & $31,035.9 \mathrm{a}$ & $1,830.1 \mathrm{a}$ & $7,795.8 \mathrm{a}$ & $20,975.7 \mathrm{a}$ & $67.3 \mathrm{a}$ \\
\hline Organic-CCI & & $29,577.1 \mathrm{a}$ & $3,302.8 \mathrm{a}$ & $7,238.9 \mathrm{a}$ & $18,898.0 \mathrm{a}$ & $64.0 \mathrm{a}$ \\
\hline Organic-RT & & $28,821.9 \mathrm{a}$ & $1,349.8 \mathrm{a}$ & $8,082.2 \mathrm{a}$ & $18,876.0 \mathrm{a}$ & $65.6 \mathrm{a}$ \\
\hline Conventional & & $28,361.9 \mathrm{a}$ & $769.0 \mathrm{a}$ & $9,764.6 \mathrm{a}$ & $17,085.1 \mathrm{a}$ & $60.8 \mathrm{a}$ \\
\hline CV $(\%)$ & & 10.5 & 53.1 & 10.7 & 12.8 & 12.0 \\
\hline $\begin{array}{l}\text { Statistics } \\
\text { Source of variation }\end{array}$ & & Total & Jumbos & Canners & No. $1 \mathrm{~s}$ & No.1s (\%) \\
\hline Year & 2 & *** & **** & NS & ** & ** \\
\hline Error a & 15 & - & - & - & - & — \\
\hline Management & 3 & ** & ${ }^{*}$ & NS & *** & ** \\
\hline Management*year & 6 & $* *$ & NS & ** & $* *$ & * \\
\hline Error b & 45 & - & - & - & - & - \\
\hline
\end{tabular}

${ }^{z}$ Yield variables were square root transformed for homogeniety of variance before analysis.

${ }^{y}$ Mean separation within column and year by Fisher's protected least significant difference (LSD) $(P \leq$ $0.05)$.

NS, *, **, *** Nonsignificant or significant at $P \leq 0.05,0.01$, or 0.0001 , respectively.

Org-NCC $=$ organically managed, no cover crop; Org-CCI = organically managed, cover crop incorporated; Org-RT = organically managed, reduced tillage.

southeastern soils as a result of low concentration of organic matter and low $\mathrm{pH}$. During dry periods, soil $\mathrm{P}$ uptake is limited by reduced water movement through the soil profile.

Sweetpotato leaf tissue was also tested for micronutrients. In 2001, Fe concentration was high to excessive in leaf tissue in all treatments, but no differences among treatments were observed (data not shown). All other micronutrients tested ( $\mathrm{Fe}, \mathrm{Mn}, \mathrm{Zn}, \mathrm{Cu}$, $\mathrm{B}, \mathrm{S}$, sodium) were within sufficiency ranges (data not shown). Although there were occasional differences among systems, differences were of little biological consequence and therefore are not presented here.

Sweetpotato vine biomass. Sweetpotato vine biomass sampled at 30, 45, and 60 DAT was influenced by a treatment-by-year interaction (data not shown); therefore, data were analyzed and are presented by year (Fig. 1). Previous work indicated 'Beauregard' foliage has maximum vine weight at $\approx 60$ DAT (Jett et al., 1998; Seem et al., 2003). In those trials, soluble conventional fertilizer was provided. In this study, organic treatments received organic forms of nutrients that must be microbially transformed to mineral forms before plant uptake. The response of foliar growth to differences in fertility sources was not clearly elucidated in this study.

In 2001, vine growth was similar among treatments at 30 and 45 DAT, but by 60 DAT, foliar biomass was greatest in the Org-NCC and lowest in Org-RT. The decline in dry weight of plants in Org-RT from 45 to 60 DAT in 2001 can be attributed to significant weed interference. In 2002, the conventionally managed system established faster and produced more foliar biomass at 30 DAT than organically managed systems. However, by $45 \mathrm{DAT}$ and continuing through $60 \mathrm{DAT}$, foliar growth in Org-CCI and Org-NCC was similar to Conv. Growth in the Org-RT system was lower than other systems at each sampling date in 2002, but lowest only at 30 DAT in 2004.

In 2002, complications related to the interaction of environmental and mechanical factors, including the transplanting method, high temperatures, and reduced soil moisture at planting, contributed to delayed sweetpotato establishment in Org-RT and subsequent growth (Fig. 1). We replaced $\approx 23 \%$ of sweetpotato plants by hand in the organically managed reduced tillage system but only $2 \%$ to $5 \%$ in the remaining systems. Although slips were irrigated with $2.5 \mathrm{~cm}$ of water $24 \mathrm{~h}$ after transplanting, subsequent plant establishment in Org-RT was slower than other systems. In 2004, the subsurface winged knife in the SST-T was omitted, and foliar biomass at 45 and 60 DAT was comparable to other systems. Other researchers have observed delayed establishment and reduced foliar biomass in reduced tillage systems. In a trial to measure soil physical properties and potato yield with a summer cover crop of sorghum sudangrass [Sorghum bicolor (L.) Moench $\times S$. sudanense (Piper) Staph.] in reduced tillage potato (Solanum tuberosum
L.), Mundy et al. (1999) observed delayed establishment and reduced plant size in notill treatments compared with conventionally managed bare soil treatments. The authors attributed these differences to increased soil bulk density as well as soil disturbance to the plant row resulting from mechanical complications at planting and subsequent weed interference.

In 2004, foliar growth was considerably higher in all systems than previous years at 45 and 60 DAT and may be associated with high soil $\mathrm{N}$ reserves at 60 DAT (Fig. 2). This observation was similar to Villagarcia et al. (1998) who observed abundant $\mathrm{N}$ may induce excessive foliar growth, sometimes at the expense of yield. Soil reserves were sufficient for sweetpotato growth for organic treatments in 2002 except for Org-RT (Fig. 2). A decline in foliar biomass in Org-RT may have been the result of low soil moisture conditions that limited $\mathrm{N}$ mineralization and $\mathrm{N}$ use.

Yield and stand. Stand counts were analyzed with SAS GLM, and after hand replanting, stand counts were found to be similar among all treatments each year (data not shown). In 2001 and 2002, roots were harvested $106 \mathrm{~d}$ after planting, and in 2004, as a result of sufficient root enlargement, roots were harvested $95 \mathrm{~d}$ after planting.

Average yields for No. 1 sweetpotato roots in North Carolina were 14,600, 17,400 , and $17,900 \mathrm{~kg} \cdot \mathrm{ha}^{-1}$ in 2001,2002 , and 2004, respectively (NCDA \& CS, 2005). In 2001, yields of No. 1 roots in our experiment were at least 54\% lower than the state average (Table 7). Yields in 2002 and 2004 were similar to or exceeded the state average yields.

Yields of No. 1 roots were similar among treatments by year except for Org-RT in 2002. In 2002, lack of soil moisture during a critical period of root expansion most likely contributed to delayed canopy development and low yields in all systems compared with other years. The reduction in yield in Org-RT in 2002 can be related to the slow rate of establishment of sweetpotato transplants as well as weed interference. In a companion paper from this study, high weed biomass in Org-RT in 2002 was negatively correlated with a decline in vine biomass at harvest (Treadwell et al., 2007). In 2004, no differences in yield among systems were observed, and yields were higher than previous years of the experiment.

Summary. Research on organic production systems can benefit both organic and conventional growers. For growers interested in transitioning to organic production, the inclusion of a conventionally managed tilled and chemical control is important because it provides conventional growers with a benchmark similar to their own systems for comparison. Although treatments in this experiment were managed organically, crop responses to long-term organic management were not captured because previous crops were produced conventionally. Benefits of improved nutrient cycling associated with the 
addition of organic matter are only fully realized in the long term when residual effects on soil microbial activity and soil fertility become apparent (Beraud et al., 2005; Gunapala and Scow, 1998; Wander and Traina, 1996).

The results from our research provide evidence that nutrients are not a limiting factor when sweetpotatoes are produced organically and that sweetpotato yields are comparable to conventionally produced sweetpotato. It is important to note that consideration was not given to roots graded unmarketable as a result of insect and disease damage. The incidence of root damage by soil-dwelling insects is a major problem in commercial sweetpotato production areas. Only recently have practices been developed to more consistently reduce pest damage by insects in a conventional production system (Abney et al., 2008). Development of a viable organic sweetpotato production system that satisfies the production criteria established by the National Organic Program will need further refinement before wide-scale commercial adoption in the southeastern United States. This research provides a beginning to better understand the use of various tillage and crop management practices in the organic production of sweetpotato and their effects on crop development and yield.

\section{Literature Cited}

Abney, M.R., G.G. Kennedy, and R. Baumler. 2008. Use of soil barrier treatments for wireworm management. Poster No.5 presented at the National Sweetpotato Collaborators Meeting, Dallas, TX, 19 Jan. 2008.

Baldwin, K.R. and J.T. Greenfield. 2006. Composting on the organic farm. Center for Environmental Farming Systems. North Carolina State University. Pub. No. E06-45788. 6 Nov. 2007. $<$ http://www.cefs.ncsu.edu/PDFs/Organic $\%$ 20Production\%20-\%20Composting.pdf $>$.

Beraud, J., P. Fine, U. Yermiyahu, M. Keinan, R. Rosenberg, A. Hadas, and A. Bar-Tal. 2005. Modeling carbon and nitrogen transformations for adjustment of compost application with nitrogen uptake by wheat. J. Environ. Qual. 34:664-675.

Cabrera, M.L., D.E. Kissel, and M.F. Vigil. 2005. Nitrogen mineralization from organic residues: Research opportunities. J. Environ. Qual. 34:75-79.

Carolina Farm Stewardship Association. 1997. Certified organic growers' manual: A guide for ecologically responsible farming practices. Pittsboro, NC.

Creamer, N.G., M.A. Bennett, and B.R. Stinner. 1997. Evaluation of cover crop mixtures for use in vegetable production systems. HortScience 32:866-870.

Creamer, N.G., M.A. Bennett, B.R. Stinner, J. Cardina, and E.E. Regnier. 1996. Mechanisms of weed suppression in cover crop-based production systems. HortScience 31:410-413.

Creamer, N.G., B. Plassman, M.A. Bennett, R.K. Wood, B.R. Stinner, and J. Cardina. 1995. A method for mechanically killing cover crops to optimize weed suppression. J. Alt. Agr. 10:157-163.

Dimitri, C. and C. Greene. 2003. Recent growth patterns in the US organic foods market. Agriculture Information Bulletin No. AIB777.
U.S. Department of Agriculture, ERS. 10 Oct. 2007. <http://www.ers.usda.gov/publications/ aib777/>.

Drinkwater, L.E., D.K. Letourneau, F. Workneh, A.H.C. van Bruggen, and C. Shennan. 1995. Fundamental differences between conventional and organic tomato agroecosystems in California. Ecol. Applic. 5:1098-1112.

Drinkwater, L.E., P. Wagoner, and M. Sarrantonio. 1998. Legume-based cropping systems have reduced carbon and nitrogen losses. Nature 396:262-265.

Gagnon, B., R.R. Simard, M. Goulet, R. Robitaille, and R. Rioux. 1998. Soil nitrogen and moisture as influenced by composts and inorganic fertilizer rate. Canadian J. Soil Sci. 78:207-215.

Gaskell, M. and R. Smith. 2007. Nitrogen sources for organic vegetable crops. HortTechnology 17:431-441.

Goncalves, J.L.M. and J.C. Carlyle. 1994. Modeling the influence of moisture and temperature on net nitrogen mineralization in a forested sandy soil. Soil Biol. Biochem. 26:1557-1564.

Gunapala, N. and K.M. Scow. 1998. Dynamics of soil microbial biomass and activity in conventional and organic farming systems. Soil Biol. Biochem. 30:805-816.

Hammett, L.K., C.H. Miller, W.H. Swallow, and C. Harden. 1984. Influence of N source, $N$ rate, and $\mathrm{K}$ rate on the yield and mineral concentration of sweetpotato. J. Amer. Soc. Hort. Sci. 109:294-298.

Hoyle, F.C., D.V. Murphy, and I.R.P. Fillery. 2006 Temperature and stubble management influence microbial $\mathrm{CO}_{2}-\mathrm{C}$ evolution and gross $\mathrm{N}$ transformation rates. Soil Biol. Biochem. 38:71-80.

Hoyt, G.D. 1999. Tillage and cover residue affects on vegetable yields. HortScience 9:351358.

International Fertilizer Industry Association. 1992. World fertilizer use manual. Paris, France.

Jackson, L.E., I. Ramirez, R. Yokota, S.A. Fennimore, S.T. Koike, D.M. Henderson, W.E. Chaney, F.J. Calderon, and K. Klonsky. 2004. On-farm assessment of organic matter and tillage management on vegetable yield, soil, weeds, pests, and economics in California. Agr. Ecosyst. Environ. 103:443-463.

Jett, L.W. 1999. Tillage methods affect the growth of sweetpotato. HortScience 34:476.

Jett, L.W. and T.P. Talbot. 1998. 1998 annual sweet potato report of Louisiana State University Sweet Potato Research Station.

Kabba, B.S. and M.S. Aulakh. 2004. Climatic conditions and crop-residue quality differentially affect $\mathrm{N}, \mathrm{P}$ and $\mathrm{S}$ mineralization in soils with contrasting P status. J. Plant Nutr. Soil Sci. 167:596-601.

Kätterer, T., M. Reichstein, O. Andrén, and A. Lomander. 1998. Temperature dependence of organic matter decomposition: A critical review using literature data analyzed with different models. Biol. Fertil. Soils 27: 258-262.

Keeney, D.R. and D.W. Nelson. 1986. NitrogenInorganic forms, p. 463-698. In: Page, A.L., R.H. Miller, and D.R. Keeney (eds.). Methods of soil analysis. Part II. Chemical and microbiological properties. 2nd Ed. Amer. Soc. of Agronomy and Soil Science Society of Amer., Inc., Madison, WI.

La Bonte, D.R., H.F. Harrison, and C.E. Motsenbocker. 1999. Sweetpotato clone tolerance to weed interference. HortScience 34:229-232.

Liebl, R., F.W. Simmons, L.M. Wax, and E.W. Stoller. 1992. Effect of rye (Secale cereale) mulch on weed control and soil moisture in soybean (Glycine max). Weed Technol. 6:838846.

Linn, D.M. and J.W. Doran. 1984. Effect of waterfilled pore space on carbon dioxide and nitrous oxide production on tilled and nontilled soils. Soil Sci. Soc. Amer. J. 48:1267-1272.

Marti, H.R. and H.A. Mills. 2002. Nitrogen and potassium nutrition affect yield, dry weight partitioning, and nutrient-use efficiency of sweetpotato. Commun. Soil Sci. Plant Anal. 33:287-301.

Mascianica, M.P., R.R. Bellinder, B. Graves, R. Morse, and H. Talleyrand. 1985. Forecasting of $\mathrm{N}$ fertilizer requirements for sweet potatoes. J. Amer. Soc. Hort. Sci. 110:358-361.

Mehlich, A. 1984. Mehlich-3 soil test extractant: A modification of Mehlich-2 extractant. Commun. Soil Sci. Plant Anal. 15:1409-1416.

Mendes, I.C., A.K. Bandick, R.P. Dick, and P.J. Bottomley. 1999. Microbial biomass and activities in soil aggregates affected by winter cover crops. J. Soil Sci. Soc. Amer. 63:873-881.

Morse, R.D., D.H. Vaughan, and L.W. Belcher. 1993. Evaluation of conservation tillage systems for transplanting crops-Potential role the subsurface tillage transplanter, p. 145-151. In: Bollich, P.K. (ed.). The evolution of conservation tillage systems. Proc. Southern Conservation Tillage Conference for Sustainable Agriculture. Monroe, LA, 15-17 June.

Mundy, C., N. Creamer, C.R. Crozier, L.G. Wilson, and R.D. Morse. 1999. Soil physical properties and potato yield in no-till subsurface-till and conventional-till systems. HortTechnology 9:240-247.

Nicholaides, J.J., III, H.F. Chancy, H.J. Mascagni, L.G. Wilson, and D.W. Eaddy. 1985. Sweetpotato response to $\mathrm{K}$ and $\mathrm{P}$ fertilization. Agron. J. 77:466-470.

North Carolina Department of Agriculture and Consumer Services. 2005. North Carolina agricultural statistics 2004. North Carolina Department of Agriculture and Consumer Services and the U.S. Department of Agriculture.

North Carolina State University and College of Agriculture and Life Sciences. 2005. North Carolina agricultural chemicals manual. AG-1. NC Coop. Ext. Serv., Raleigh, NC.

Organic Trade Association. 2006. Organic Trade Association's 2006 manufacturer survey overview. 10 Oct. 2007.<http://www.ota.com/pics/ documents/short $\% 20$ overview\%20MMS.pdf>.

Phillips, S.B., J.G. Warren, and G.L. Mullins. 2005. Nitrogen rate and application timing affect 'Beauregard' sweetpotato yield and quality. HortScience 40:214-217.

Purcell, A.E., W.M. Walter, Jr., J.J. Nicholaides, W.W. Collins, and H. Chancy. 1982. Nitrogen, potassium, sulfur fertilization and protein content of sweet potato roots. J. Amer. Soc. Hort. Sci. 107:425-427.

Ranells, N.N. and M.G. Wagger. 1997. Grasslegume bicultures as winter annual cover crops. Agron. J. 89:659-665.

Raviv, M. 2005. Production of high-quality composts for horticultural purposes: A mini-review. HortTechnology 15:52-57.

Reberg-Horton, S.C., J.D. Burton, D.A. Danehower, G. Ma, D.W. Monks, J.P. Murphy, N.N. Ranells, J.D. Williamson, and N.G. Creamer. 2005. Changes over time in the allelochemical content of ten cultivars of rye (Secale cereale L.). J. Chem. Ecol. 31:179-193.

Rolston, L.H., C.A. Clark, J.M. Cannon, W.M. Randle, E.G. Riley, P.W. Wilson, and M.L. Robbins. 1987. 'Beauregard' sweet potato. HortScience 22:1338-1339. 
Schultheis, J.R. and W.S. Jester. 2002. Nitrogen fertilizer management in 'Beauregard' sweetpotatoes, p. 188-192. In: Nakatani, M. and K. Komaki (eds.). Potential of root crops for food and industrial resources. Twelfth Symp. Intl. Soc. for Root Crops. 10-16 Sept., Tsukuba, Japan. Cultio Corp., 4-1-12 Kasuga, Tsukuba, Ibaraki 305-0821 Japan.

Schultheis, J.R., S.A. Walters, D.E. Adams, and E.A. Estes. 1999. In-row plant spacing and date of harvest of 'Beauregard' sweetpotato affect yield and return on investment. HortScience 34:1229-1233.

Scow, K.M., O. Somoasco, N. Gunapala, S. Lau, R. Venette, H. Ferris, R. Miller, and C. Shennan. 1994. Transition from conventional to lowinput agriculture changes soil fertility and biology. Calif. Agr. 48:20-26.

Seem, J.E., N.G. Creamer, and D.W. Monks. 2003. Critical weed-free period for 'Beauregard' sweetpotato (Ipomoea batatas). Weed Tech. 17:686-695.

Senesvirante, G., L.H.J. Van Holm, and S.A. Kulasooriya. 1998. Quality of different mulch materials and their decomposition and $\mathrm{N}$ release under low moisture regimes. Biol. Fertil. Soils 26:136-140.

Shipley, P.R., J.J. Meisinger, and A.M. Decker. 1992. Conserving residual corn fertilizer nitrogen with winter cover crops. Agron. J. 85:673680 .

Stark, J.M. and M.K. Firestone. 1995. Mechanisms for soil moisture effects on activity of nitrifying bacteria. Appl. Environ. Microbiol. 61:218-221.
Statistical Analysis Systems. 2001. Statistical Analysis Systems Institute, Cary, NC.

Staver, K.W. and R.B. Brinsfield. 1998. Using cereal grain winter cover crops to reduce groundwater nitrate contamination in the midAtlantic coastal plains. J. Soil Water Cons. 53:230-240.

Stinner, B.R., G.D. Hoyt, and R.L. Todd. 1983. Changes in soil chemical-properties following a 12-year fallow- a 2-year comparison of conventional tillage and no-tillage agroecosystems. Soil Tillage Res. 3:277-290.

Stone, A.G., G.E. Vallad, L.R. Cooperband, D. Rotenberg, H.M. Darby, R.V. James, W.R. Stevenson, and R.M. Goodman. 2003. Effect of organic amendments on soilborne and foliar diseases in field-grown snap bean and cucumber. Plant Dis. 87:1037-1042.

Toth, S.J., T. Melton, D.W. Monks, J.R. Schultheis, and K.A. Sorensen. 1997. Sweetpotato pesticide use survey in North Carolina. Data report for the Southern Region Pesticide Impact Assessment Program. North Carolina State University, Raleigh, NC.

Treadwell, D.D., N.G. Creamer, J.R. Schultheis, and G.D. Hoyt. 2007. Cover crop management affects weeds and yield in organically managed sweetpotato systems. Weed Tech. 21:1039-1048.

U.S. Department of Agriculture. 1981. U.S. standards for grades of sweetpotatoes. U.S. Department of Agricultural Marketing Service, Washington, DC.

U.S. Department of Agriculture and the Agricultural Marketing Service. 2002. National organic standards. Docket No. TMD-00-02FR. 10 Jan. 2004. <http://www.ams.usda.gov/ nop/indexIE.htm>.

U.S. Department of Agriculture and the Soil Conservation Service. 1974. Soil survey of Wayne County, NC.

Varco, J.J., W.W. Frye, M.S. Smith, and C.T. MacKown. 1989. Tillage effects on nitrogen recovery by corn from a N-15 labeled legume cover crop. Soil Sci. Am. J. 53:822827 .

Villagarcia, M.R., W.W. Collins, and C.D. Raper. 1998. Nitrate uptake and nitrogen use efficiency of two sweetpotato genotypes during early stages of root formation. J. Amer. Soc. Hort. Sci. 123:814-820.

Wagger, M.G. 1989. Time of desiccation effects on plant composition and subsequent nitrogen release from several winter annual cover crops. Agron. J. 81:236-241.

Wander, M.M. and S.J. Traina. 1996. Organic matter fractions from organically and conventionally managed soils: I. Carbon and nitrogen distribution. Soil Sci. Soc. Amer. J. 60:10811087.

Wilson, D.O. and W.L. Hargrove. 1986. Release of nitrogen from crimson clover residue under two tillage regimes. Soil Sci. Amer. J. 50:12511254

Wilson, G.L., C.W. Averre, J.V. Baird, E.O. Beasley, A.R. Bonanno, E.A. Estes, and K.A. Sorensen. 1989. Growing and marketing quality sweetpotatoes. Agric. Ext. Serv. Pub. No. AG-09. 